\title{
dCREB2-Mediated Enhancement of Memory Formation
}

\author{
Thomas C. Tubon Jr, ${ }^{1,3,8}$ Jiabin Zhang, ${ }^{1,4}$ Eugenia L. Friedman, ${ }^{1,4}$ Haining Jin, ${ }^{5}$ Erin D. Gonzales, ${ }^{1,6}$ Hong Zhou, ${ }^{1}$ \\ Diana Drier, ${ }^{7}$ Jason R. Gerstner, ${ }^{9}$ Emily A. Paulson, ${ }^{1}$ Robin Fropf, ${ }^{1,4}$ and Jerry C. P. Yin ${ }^{1,2}$ \\ Departments of ${ }^{1}$ Genetics and ${ }^{2}$ Neurology, ${ }^{3}$ Institute on Aging, ${ }^{4}$ Neuroscience Training Program, ${ }^{5}$ Department of Human Oncology, Wisconsin Institute of \\ Medical Research, ${ }^{6}$ Cell and Molecular Biology Graduate Program, and 7Waisman Center, University of Wisconsin-Madison, Madison, Wisconsin 53706, \\ ${ }^{8}$ Madison College, Madison, Wisconsin 53704, and ${ }^{9}$ Center for Sleep, University of Pennsylvania, Philadelphia, Pennsylvania 19104
}

CREB-responsive transcription has an important role in adaptive responses in all cells and tissue. In the nervous system, it has an essential and well established role in long-term memory formation throughout a diverse set of organisms. Activation of this transcription factor correlates with long-term memory formation and disruption of its activity interferes with this process. Most convincingly, augmenting CREB activity in a number of different systems enhances memory formation. In Drosophila, a sequence rearrangement in the original transgene used to enhance memory formation has been a source of confusion. This rearrangement prematurely terminates translation of the full-length protein, leaving the identity of the "enhancing molecule" unclear. In this report, we show that a naturally occurring, downstream, in-frame initiation codon is used to make a dCREB2 protein off of both transgenic and chromosomal substrates. This protein is a transcriptional activator and is responsible for memory enhancement. A number of parameters can affect enhancement, including the short-lived activity of the activator protein, and the time-of-day when induction and behavioral training occur. Our results reaffirm that overexpression of a dCREB2 activator can enhance memory formation and illustrate the complexity of this behavioral enhancement.

\section{Introduction}

The cAMP signaling pathway, which includes protein kinase A and the transcription factor cAMP-response element-binding (CREB) protein, is found in all cell types. CREB binds to the cAMP-response element (CRE) sequence and stimulates transcription. In the nervous system, CREB mediates systemic and cellular responses to a diverse set of physiological stimuli, including stress, metabolism, drugs of abuse, circadian rhythms, and learning and memory (Shaywitz and Greenberg, 1999; Lonze and Ginty, 2002; Alberini, 2009). It is unclear how such a commonly recruited pathway results in specific physiological responses. One possibility is that the pathway is used broadly to mediate change from a previously established baseline. This role in "adaptive change" is consistent with the pathway responding to many different and diverse signals (Tao et al., 1998).

Many experimental approaches have been used to show the involvement of the CREB family of transcription factors in longterm memory (LTM) formation (Izquierdo et al., 2002; Josselyn and Nguyen, 2005; Miyamoto, 2006). Correlative experiments have shown the activity-dependent phosphorylation and activa-

\footnotetext{
Received Sept. 13, 2012; revised Feb. 11, 2013; accepted March 20, 2013.

Author contributions: T.C.T. and J.C.P.Y. designed research; T.C.T., J.Z., E.L.F., H.J., E.D.G., H.Z., D.D., J.R.G., E.A.P., and R.F. performed research; T.C.T., J.Z., E.L.F., and J.C.P.Y. analyzed data; E.D.G. and J.C.P.Y. wrote the paper.

This work was supported through NIH funding to J.C.P.Y. (R01s NS35575, HL/AR59649, NS063245 and funding from the McKnight Foundation). Additional funding support was provided through the UW-Madison Institute of Aging (to T.C.T.) and the Neuroscience Training Program (to E.L.F., J.R.G., and R.F.). Toshihiro Kitamoto, Steve de Belle, Chris Tabone, and Eric Drier provided important technical assistance and advice.

The authors declare no competing financial interests.

Correspondence should be addressed to Jerry C. P. Yin, 3434 Genetics/Biotechnology, 425 Henry Mall, Madison, Wisconsin 53706. E-mail: jcyin@wisc.edu.

DOI:10.1523/JNEUROSCI.4387-12.2013

Copyright $\odot 2013$ the authors $\quad 0270-6474 / 13 / 337475-13 \$ 15.00 / 0$
}

tion of this family of transcription factors (Impey et al., 1998; Schulz et al., 1999; Ahmed and Frey, 2005; Leutgeb et al., 2005; Alzoubi and Alkadhi, 2007; Hotte et al., 2007). "Loss-offunction" experiments have disrupted protein activity, resulting in a parallel interference with the formation of LTM (Dash et al., 1990; Yin et al., 1994; Guzowski and McGaugh, 1997; Lamprecht et al., 1997; Josselyn et al., 2001; Kida et al., 2002; Bozon et al., 2003; Zhang et al., 2003; Josselyn et al., 2004; Brightwell et al., 2005; Warburton et al., 2005; Mouravlev et al., 2006). Most remarkably, "gain-of-function" experiments have augmented gene activity and resulted in enhancement of memory formation and plasticity (Yin et al., 1995a; Davis et al., 1996; Bartsch et al., 1998; Josselyn et al., 2001; Barco et al., 2002; Barco et al., 2005; Jasnow et al., 2005; Wagatsuma et al., 2006; Brightwell et al., 2007; Han et al., 2008). It is striking that a transcription factor, implicated in the regulation of hundreds of genes, and capable of responding to a wide variety of signals, can enhance such an apparently specific process as memory formation.

In our original Drosophila papers, a dCREB2-encoded protein was shown to be a CRE-binding, PKA-dependent transcriptional activator, and when induced in transgenic flies, was able to enhance the process of LTM formation (Yin et al., 1995a,b; Yin and Tully, 1996). Perazzona et al. (2004) reported a sequence rearrangement in the transgene and the inability to reproduce behavioral enhancement. For many years, our goals have been to determine the biological product that is able to enhance memory formation, and to understand why behavioral enhancement is not consistent.

In this report, we identify the transgenic protein responsible for behavioral enhancement, and some factors that can contribute to enhancement of olfactory avoidance. We also demonstrate 
A
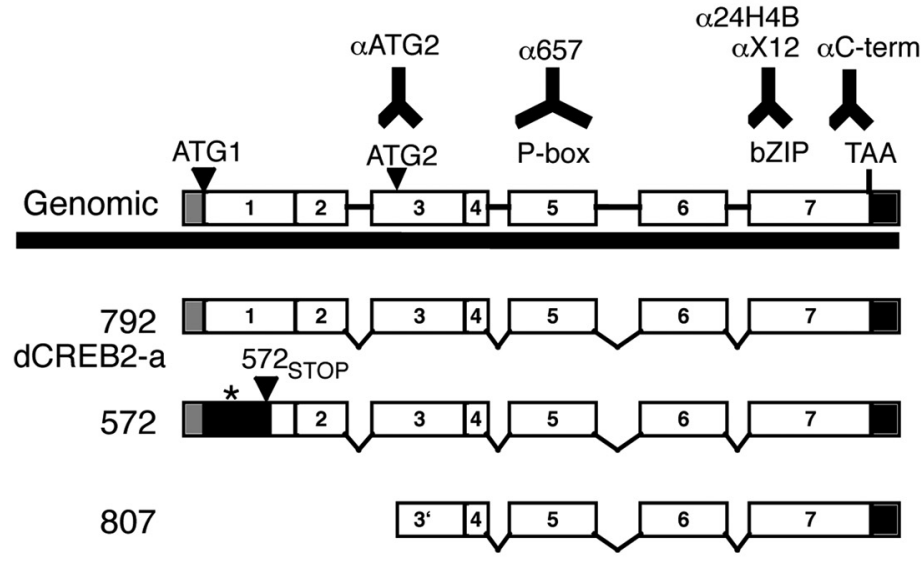

C

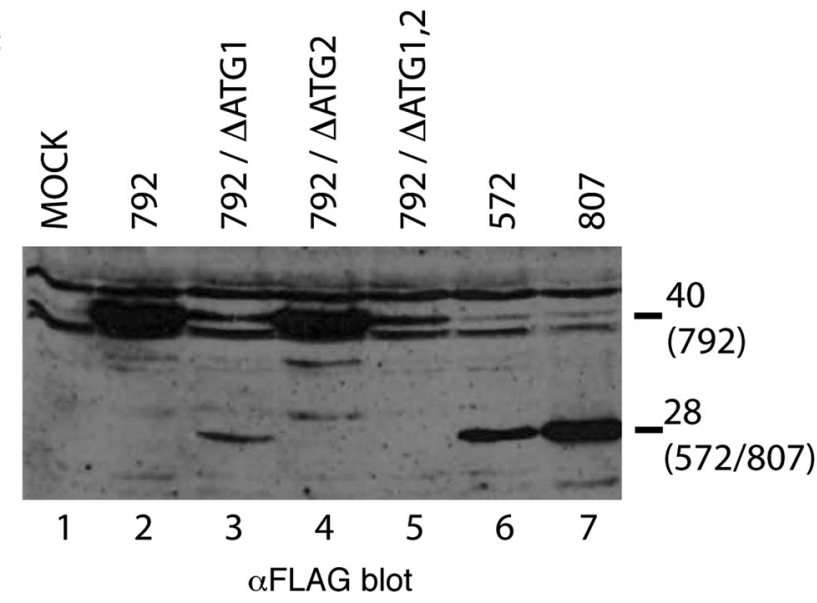

B

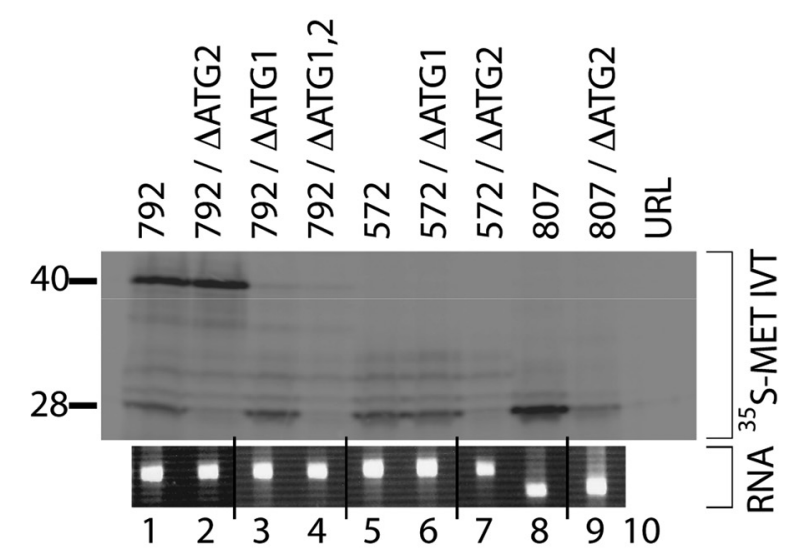

D

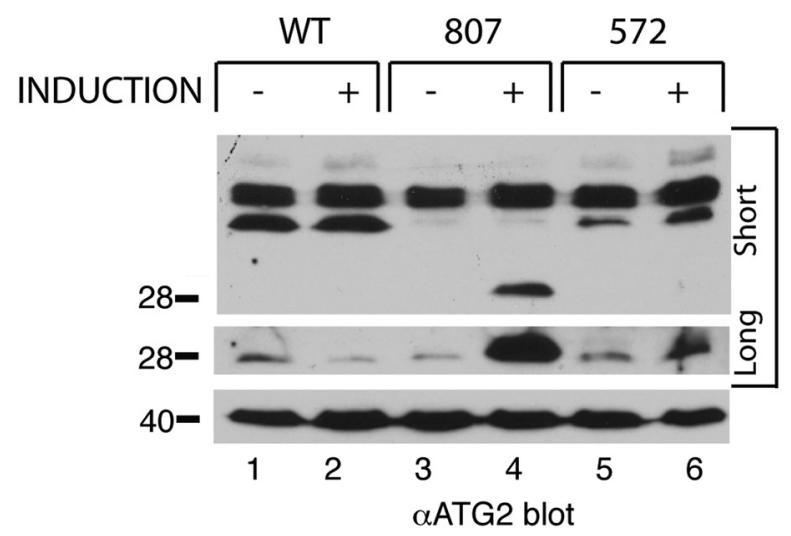

Figure 1. The 572 transgene expresses a $28 \mathrm{kDa}$ CRE-binding protein. A, Schematic organization of the dCREB2 locus. Exons $1-7$ of the dCREB2 locus are boxed, and the ATG1, ATG2, and TAA (stop) codons are shown. 792 is the previously identified dCREB2-a isoform. 572 is identical to 792 except it contains a frameshift mutation $(*)$ that results in a premature translational stop within exon 1 $\left(572_{\text {sTop }}\right)$, indicated by an arrowhead. The 807 ORF initiates from the ATG2 located within exon 3 . The epitopes of the various antibodies are indicated. B, ATG1 and ATG2 are used to initiate translation in rabbit reticulocyte lysates. Equivalent amounts of RNA transcripts (bottom) are used to program reticulocyte lysates. Translation products are labeled with ${ }^{35} \mathrm{~S}$-Met and resolved by SDS PAGE. $\triangle$ ATG1, $\triangle$ ATG2, or $\triangle$ ATG1/ATG2 indicate base substitutions from ATG to ATT. C, ATG1 and ATG2 are used in transiently transfected cells. Equal amounts of plasmid DNA encoding various ORFs fused to a FLAG epitope are transfected into $\mathrm{S} 2$ cells, allowed to express, and equivalent amounts of cell lysate are analyzed using Western blots probed with an $\alpha \mathrm{FLAG}$-specific antibody. D, Induction of the 572 and 807 transgenes make a protein with an apparent mobility of $28 \mathrm{kD}$. Head extracts from heat-shock-induced ( + ), or not ( - ), wild type (WT), 807 or 572 flies analyzed using Western blots probed with the ATG2 antibody (top two panels) or the 657 antibody (bottom panel). The top panel is a short exposure, while the middle panel shows the region around $28 \mathrm{kD}$ upon a longer exposure. The bottom panel shows a window that was stripped and reprobed with the 657 antibody.

transgenic enhancement of conditioned courtship suppression. Our data support a model where multiple factors influence memory enhancement and provides tools to identify some of the unknown ones.

\section{Materials and Methods}

DNA constructs, transgenic flies. The experiments in this report rely upon a number of different dCREB2 open reading frames (ORFs) that are expressed in vitro, in transfected cells, or in transgenic flies, and they are shown in Figure $1 A$. Standard recombinant DNA procedures were used to move these different ORFs between plasmid vectors. The diagram that is labeled "Genomic" shows the exon/intron organization of the dCREB2 locus. Exons are boxed and numbered, while introns are indicated with horizontal lines that connect the boxes. Noncoding exons (shaded boxes) are not shown in detail. 792 [originally named dCREB2-a in the study by Yin et al. (1995b); identified as NM206784 in the Fly Genome Sequencing Project; also known as CG6103-RE in Flybase] is a cDNA that results from the splicing of exons $1-7$, and is predicted to make a 330 aa protein whose translation initiates at the first start codon designated ATG1. This ORF, and the protein that it makes, whether in vitro, in cells, or in transgenic flies, will be referred to as 792 . This is the cDNA that we intended to express in our original studies of the dCREB2 activator, whether transfected into cells or used to make transgenic flies (Yin et al., 1995a,b).

The 572 ORF is identical to 792 except that it contains a sequence rearrangement early in exon 1 (indicated with an asterisk), and a subsequent translation termination codon (at the site denoted $\mathrm{STOP}_{572}$ ). This rearranged coding region is referred to as 572 , whether it is used for in vitro experiments, is transfected into cells, or is used to make transgenic flies. This construct is the one that was used in previous publications (Yin et al., 1995a,b) and is the source of the confusion (Perazzona et al., 2004). Inspection of the sequence of the 572 and 792 ORFs revealed the presence of ATG2, a downstream, in-frame methionine codon shown in Figure $1 A$. Translation could potentially initiate, or reinitiate at ATG2, downstream of the 572 rearrangement and resulting STOP ${ }_{572}$. The 807 ORF contains $65 \mathrm{nt}$ upstream of the ATG2 codon, and the rest of the dCREB2-a ORF. The 5' end of the ORF was made using a nearby AvaI site, which was cut, treated with mung bean nuclease, and blunt-end ligated to a blunt end site on a cloning vector. These different ORFs will be referred to as 572,792 , or 807 whether they are expressed in vitro, in transfected cells, or in transgenic flies.

For the in vitro translation reactions, site-directed mutagenesis of the ORFs was performed in $\mathrm{pKS}+$ using Quikchange (Stratagene) to change 
ATG start codons to AUU, sequenced, and named: pJY2715 (792 $\Delta$ ATG1), pJY2716 (792 $\Delta$ ATG2), pJY2717 (792 $\Delta$ ATG1/DATG2), pJY2719 (572 $\Delta$ ATG1), pJY2720 (572 $\Delta$ ATG2), pJY2721 (572 $\Delta$ ATG1/ $\Delta$ ATG2), and pJY2718 (807 $\Delta$ ATG2). For the transient transfection assays, site-directed mutagenesis was used to create each of the mutations (ATG to CTG substitutions). The ORFs were amplified using primers to create a 5' KpnI site and a 3'-FLAG epitope placed 5' to the stop codon, preceding a XhoI site. These KpnI/XhoI fragments were subcloned into the pActinP vector, the ORFs resequenced, and named: pJY2801 (792), pJY2802 (792 $\Delta$ ATG1), pJY2803 (792 $\Delta$ ATG2), pJY2804 (792 $\Delta$ ATG1/ $\Delta$ ATG2), pJY2805 (572), and pJY2806 (807). For generating transgenic flies, the 572, 807 and 792 ORFs were subcloned into the CaSpeRhs vector, producing pJY572, pJY806, and pJY807. The inserts were sequenced, and standard procedures were used to make transgenic fly lines in the $w$ iso (CJ1) line. These transgenic lines are referred to as 572, 807, and 792 .

In vitro transcription/translation. In vitro transcription templates were prepared by digesting plasmids with SalI (New England Biolabs) followed by gel purification using Qiagen Gel Purification columns (Qiagen). Templates were normalized to $1 \mu \mathrm{g}$ and transcribed with T7 RNA Polymerase (Fermentas). In vitro transcribed RNA was normalized by spectrophotometry and checked by RNase-free agarose gel before translation. DNase-treated, in vitro transcribed RNA ( $2 \mu \mathrm{g}$ total) was denatured at $65^{\circ} \mathrm{C}$ for $5 \mathrm{~min}$ and plunged onto ice immediately before translation. Translation was performed with Nuclease-treated Rabbit Reticulocyte Lysate (Promega) according to manufacturer's instructions using incorporation of $\left[{ }^{35} \mathrm{~S}\right]$ methionine $(1200 \mathrm{Ci} / \mathrm{mmol}$ at $10 \mathrm{mCi} / \mathrm{ml})$ (GE Healthcare). Translation was terminated after $90 \mathrm{~min}$ and products were resolved on a $12 \%$ polyacrylamide-SDS gel at $110 \mathrm{~V}$ for $120 \mathrm{~min}$. The gel was then electrophoretically transferred to nitrocellulose and analyzed using a Molecular Dynamics Storm 860 with Image Quant 5.2 software (GE Healthcare).

$R T-P C R$. Three different genotypes of flies [2U (wild-type), 807 and $\Delta$ ATG2] were entrained on a $12 / 12 \mathrm{~h}$ lights on/lights off schedule. Flies were divided into two groups and moved into empty plastic vials containing $3 \mathrm{~m}$ paper for climbing. One group was heat shock-induced (HS) in a $37^{\circ} \mathrm{C}$ circulating water bath for $30 \mathrm{~min}$ at $\mathrm{ZT}=6$; the control group (NHS) was maintained at $22^{\circ} \mathrm{C}$ for the duration of the heat shock period. Immediately after the end of heat shock (at ZT $=8$ ), both groups of flies were transferred back to vials containing standard food for a $90 \mathrm{~min}$ recovery period, after which all flies were transferred into empty plastic vials and immediately frozen in liquid nitrogen. Heads were collected on dry ice and maintained at $-80^{\circ} \mathrm{C}$ until RNA extraction.

Total RNA was extracted from all groups of heads by homogenizing heads with a Teflon pestle in TRIZOL (Invitrogen) per manufacturer's instructions. Total RNA was reextracted using acidic phenol, $\mathrm{pH} 4.5$, and precipitated with GlycoBlue (Ambion). Total RNA concentrations were quantified by spectrophotometry using the NanoDrop (ThermoScientific) and diluted to standard amounts for blotting and RT-PCR. Nanodrop was used to quantitate the amount of mRNAs.

RT-PCR was performed using primer pair T2 (5' GATTCTCCAGGC ACTTGATGTACTCC 3') /B6 (5' GCCGTCGTACAATAAGATCTTC ACC $\left.3^{\prime}\right)$. B6 was used as a dCREB2-specific primer for reverse transcription; RT-PCR was performed with $25 \mathrm{ng}$ of total RNA from each sample with SuperScript III Platinum One-Step Quantitative RT-PCR System (Invitrogen Cat. No. 11732-020) as per manufacturer's instructions. Samples were processed with Platinum Taq alone (Invitrogen) in parallel to verify that samples were free of genomic DNA contamination. Ten percentage of final products were used for quantification by ethidium bromide staining.

Transfection and Schneider cell culture. For transient transfection assays, Schneider cells were seeded at a density of $3.0 \times 10^{6}$ cells in a $2 \mathrm{ml}$ volume of medium (source) per $15 \mathrm{~mm}$ well of a 6-well plate. Effectine (Qiagen) transfection was performed $8 \mathrm{~h}$ later with the addition of $0.5 \mu \mathrm{g}$ of each respective plasmid DNA, and cells were incubated at $25^{\circ} \mathrm{C}$ for $48 \mathrm{~h}$. Cells were harvest by centrifugation and resuspended in $100 \mu \mathrm{l}$ of $1 \times$ Laemmli buffer. The samples were then boiled for $5 \mathrm{~min}$ at $95^{\circ} \mathrm{C}$ and $10 \mu \mathrm{l}$ was analyzed by Western blot using the polyclonal anti-Flag antibody (Sigma-Aldrich).
Extract preparation. All extracts used for immunoprecipitation, Western blotting, and electrophoretic mobility shift assays (EMSA) were prepared from isolated fly heads. Rapid freezing in liquid nitrogen was used to kill the flies. Frozen flies were vortexed to sever heads, which were isolated via filtration through a 710 micron sieve. Isolated heads were homogenized using a motorized Teflon tissue homogenizer in HB buffer (15 mu HEPES, pH 7.5, $10 \mathrm{~mm} \mathrm{KCl,} 5$ mm $\mathrm{MgCl}_{2}, 0.1$ mм EDTA, $0.5 \mathrm{~mm}$ EGTA, 1 mM DTT, 1 mM PMSF) supplemented with Roche Complete Protease Inhibitors (Roche Diagnostics). For homogenates prepared from heat-shock induced lines, flies were exposed to a $60 \mathrm{~min}$ heat-shock at $37^{\circ} \mathrm{C}$ (in an air incubator) and then returned to $25^{\circ} \mathrm{C}$ for a $2 \mathrm{~h}$ recovery period before harvest.

Antibodies and Western blotting. The top of Figure $1 A$ shows a diagram of the epitopes of the different antibodies that were used in this study. The following antibodies are used in this report: anti-CREB antibodies C21 (SC-186), 24H4B (SC-271), and X12 (SC-240), and are all from Santa Cruz Biotechnology. The $\mathrm{C} 21$ antibody was raised against a peptide from the bZIP region of human CREB that is $89 \%$ identical to the corresponding stretch of amino acids in dCREB2 (M. DeGiovanni, personal communication) (Santa Cruz Biotechnology). X12 and 24H4B were raised against the last 73 aa of the human CREB protein (Santa Cruz Biotechnology). This includes the bZIP domain, which is identical between dCREB2 and CREB in 45 of the 49 residues, with neutral changes in 2 out of the 4 nonidentical amino acids. For Western blotting, C21 was used at a dilution of 1:1000. The dCREB2-specific monoclonal antibody $\alpha 657$ was raised in mouse against purified, recombinant dCREB2-b protein, and has been previously described (Belvin et al., 1999; Horiuchi et al., 2004) and used at a dilution of 1:50 for Western blotting. Rabbit polyclonal antibody $\alpha \mathrm{Ab} 8$ was generated against the dCREB2 bZIP peptide $\mathrm{NH}_{2}$-RKREIRLQKNREAAREC-COOH, which was conjugated to keyhole limpet hemocyanin using an Imject Immunogenic EDC conjugation kit (Pierce) before immunization. The peptide was cross-linked to agarose beads in a column (AminoLink immobilization kit, Pierce). Ammonium sulfate cuts $(25 \%$, then $50 \%$ ) were performed on total sera. The pellet was resuspended in PBS and dialyzed into PBS before binding it to the peptide column. The antibody-containing fraction was eluted from the column using a low $\mathrm{pH}$ buffer (100 mM glycine, $\mathrm{pH} 2.5)$, neutralized, dialyzed against PBS, and stored in PBS $+10 \%$ glycerol at $-80^{\circ} \mathrm{C}$. It was used at a 1:500 dilution for Western blotting. Rabbit polyclonal antibody $\alpha \mathrm{C}$-term was raised against the dCREB2 C-terminal peptide $\mathrm{NH}_{2}$ ELKSLKELVCQTKND-COOH, which was conjugated to keyhole limpet hemocyanin using an Imject Immunogen EDC conjugation kit (Pierce) before immunization. The subsequent steps were identical as those for $\alpha \mathrm{Ab} 8$, except antibodies were affinity purified by passage through a dCREB2 C-terminal peptide antigen column. The $\alpha$ ATG2 antibody was made commercially (Yenzym), using a peptide that contained residues downstream of ATG2 as the immunogenic peptide. The peptide was conjugated and injected into rabbits. Antiserum was partially purified using a two-step procedure. A second peptide that contained residues both N- and C-terminal to ATG2 was used to make a peptide column, and the antisera from different rabbits were passed through this column. The flow through from this first column was then applied to a second affinity column that contained the immunogenic peptide conjugated to resin. The bound protein was eluted and used at a 1:1000 dilution for Western blotting. For tissue culture-based experiments, polyclonal antiFlag (Sigma-Aldrich) antibody was used at a dilution of 1:3000 to detect Flag epitope-tagged CREB proteins. Standard molecular biology procedures for Western blotting were performed with ECL detection using the Supersignal West Pico Chemiluminescent Substrate Kit (Pierce).

Immunoprecipitation. The following antibodies were used for immunoprecipitation reactions: $\alpha \mathrm{C} 21, \alpha 657,24 \mathrm{H} 4 \mathrm{~B}$, and X12. For each independent IP reaction, $100 \mu \mathrm{l}$ of head extract $(\sim 100-150 \mu \mathrm{g}$ of protein) were prepared from wild-type and transgenic fly heads, and incubated with $1 \mu \mathrm{l}$ of the specified anti-CREB antibody with rotation at $4^{\circ} \mathrm{C}$ for 60 min. Protein A-Agarose (Sigma-Aldrich), or protein G-Sepharose (Genscript) resins were used to precipitate CREB-containing complexes isolated using monoclonal or polyclonal CREB antibodies, respectively. For each reaction, $12.5 \mu \mathrm{g}$ of resin was added to the extracts containing the specified antibody, and allowed to incubate with rotation for $4 \mathrm{~h}$ at $4^{\circ} \mathrm{C}$. 
Antibody-bound resins were then isolated by centrifugation at $1000 \times g$ for $5 \mathrm{~min}$, and washed five times in buffer D50 (20\% glycerol, $20 \mathrm{~mm}$ HEPES, pH 7.0, 50 mm KCl, 0.2 mм EDTA, 3 mm DTT, 0.05\% Tween 20, and $0.5 \mathrm{~mm}$ PMSF). After the final wash, the resins were aspirated and resuspended in $40 \mu \mathrm{l}$ of Laemmli protein buffer and heated for $10 \mathrm{~min}$ at $95^{\circ} \mathrm{C}$. The immunocomplexes were resolved on a $12 \%$ SDS-PAGE gel, and analyzed by Western blotting.

EMSA. Electrophoretic mobility shift assays were performed using ${ }^{32} \mathrm{P}$-labeled DNA probes. The PKM-CRE probe was amplified using PCR off of the genomic Drosophila aPKC sequence corresponding to intron C, and was subcloned creating $\mathrm{pJY} 2300$. The PCR primers for amplification of the PKM-CRE probe is 5'-TGTACACGCCCATAGATT- $3^{\prime}$ and $5^{\prime}$ TAGAATCCGATCCAGAGT- $3^{\prime}$. The PKM CRE probe is $126 \mathrm{bp}$ with the CRE element centered (underlined) and flanked at both ends by endogenous PKM promoter sequences: 5' -TGTACACGCCCATAGATTACTC AGTTTTTCTTTTTATAGAACTGTAATATTTATAAACTAATGACGT AATAATGAGCAGATAGTAATTTACTTTCTCTACTGATTAGCAT TGGAAATTAAAGCATT-3'. Double stranded PCR templates were isolated by electrophoresis on $0.8 \%$ agarose followed by band excision and purification via QiaQuick (Qiagen). The PKM-CRE template was then end-labeled with $\gamma^{32} \mathrm{P}$-ATP using T4 PNK for $60 \mathrm{~min}$ at $37^{\circ} \mathrm{C}$. Free unincorporated ${ }^{32} \mathrm{P}$ ATP was removed by passage through a G50 column (GE Healthcare). The labeled double stranded probe was then separated on a $4 \% \mathrm{TGE}+2 \mathrm{~mm} \mathrm{MgCl}_{2}$ gel. After positive identification via autoradiogram, the double stranded PKM-CRE probe was excised from the gel, and eluted overnight in TBE. The CPM per microliter of probe was determined by scintillation count, and $10 \mathrm{~K}$ CPM was used in each EMSA reaction.

Protein and DNA probes were incubated for $1 \mathrm{~h}$ in EMSA Binding Buffer (12 mм HEPES pH 7.9, 4 mm Tris Cl pH 7.9, 1 mm EDTA, 12\% glycerol, $1 \mathrm{~mm}$ DTT, $5 \mathrm{~mm} \mathrm{MgCl}_{2}, 60 \mathrm{~mm} \mathrm{KCl}, 1 \mathrm{mg} / \mathrm{ml} \mathrm{BSA}$, and 0.4 $\mathrm{mg} / \mathrm{ml}$ poly dIdC), followed by product resolution on a $4.5 \% \mathrm{TGE}+2 \mathrm{mM}$ $\mathrm{MgCl}_{2}$ gel. For supershift experiments, 1-3 $\mu \mathrm{l}$ of each corresponding antibody was added to the EMSA binding reaction.

Luciferase reporter assay. Wild-type 2202U, 572, and 807 flies were crossed to the $3 \times$ CRE-luciferase reporter flies (Belvin et al., 1999). For each line, 20 trans-heterozygous offspring were collected from the mating and placed into vials containing standard media. Flies were then entrained to a $12 / 12 \mathrm{~h}$ light/dark cycle for $72 \mathrm{~h}$ at $25^{\circ} \mathrm{C}$. At ZT11 of the fourth day, all animals were transferred to a $37^{\circ} \mathrm{C}$ air incubator for $60 \mathrm{~min}$ to induce protein expression, and immediately returned to $25^{\circ} \mathrm{C}$ to recover. Material for the initial time point was collected before the temperature shift at ZT11 and then again directly preceding the $60 \mathrm{~min}$ induction period. Additional samples were collected at $30 \mathrm{~min}$ intervals following the end of heat shock. For each time point, collected flies were flash frozen into liquid nitrogen, followed by head isolation and extract preparation in standard HB buffer as described above. Total protein concentration of each extract was measured using the Bio-Rad AC DC protein assay kit and UV spectrophotometry. Protein concentration between samples was normalized and equivalent amounts of protein were used in each luciferase reaction. Luciferase activity was measured manually using the Bright-Glo Luciferase Assay (Promega). Activity was measured within the linear range of luciferase activity $\left(1 \times 10^{4}\right.$ to $\left.1 \times 10^{6}\right)$ and signals were standardized to 100 Relative Luciferase Units (RLU) at $t=0$. The experiment was performed in triplicate for each time point, and the data were imported into EXCEL for analysis.

Sequence alignment and phylogenetic map. Genomic sequences for $D$. melanogaster (CG6103), D. yakuba (dsim_GLEANR_17523), D. erecta (dana_GLEANR_6401), D. pseudoobscura (Dpse/GA19353), D. persimillis (dper_GLEANR_9567), D. willistoni (dwil_GLEANR_2604), and D. grimshawi (dgri_GLEANR_2152) were accessed from Flybase (www. flybase.org). mRNA transcripts were assembled according to splice site predictions using the Berkeley Drosophila Genome Project prediction program for splicing and translated into the corresponding protein sequence. Alignment was performed using ClustalW2, and annotated in Microsoft Word. A standard phylogenetic tree of Drosophila species was used.

Olfactory memory. Flies were trained using the olfactory-avoidance conditioning paradigm (Tully and Quinn, 1985) modified to enable automated repetitive training (Tully et al., 1994). 3-octanol and 4-methylcyclohexanol were used as the odorants. A single training trial consists of a $90 \mathrm{~s}$ exposure to ambient air; $60 \mathrm{~s}$ of electric shock (the unconditioned stimulus) delivered as $70 \mathrm{~V}$ pulses lasting $1.5 \mathrm{~s}$ and administered every $5 \mathrm{~s}$ ( 12 total) accompanied by simultaneous exposure to one odor (the conditioned stimulus, $\mathrm{CS}+$ ); $45 \mathrm{~s}$ of ambient air exposure to clear the first odor; $60 \mathrm{~s}$ of exposure to the second odor, with no shock (the CS - condition), and $45 \mathrm{~s}$ of ambient air to clear the second odor. Three cycles of massed training consists of three individual trials done consecutively with no intertrial interval. Testing was done by placing flies in a choice point and allowing them to decide between the CS+ and CSstimuli for $2 \mathrm{~min}$. The performance index $=$ (the number of flies making the correct choice) - (the number of flies making the incorrect choice/ total number of flies, multiplied by 100 . To avoid odor-avoidance biases, we calculate the performance index of each single $\mathrm{N}$ by taking an average performance of two groups of flies, one trained with 3-octanol as CS + , the other with 4-methylcyclohexanol. In all behavior experiments, $n=8$. Training is conducted under red light, at $25^{\circ} \mathrm{C}$ and $\sim 50 \%$ humidity.

Heat-shock induced flies were placed in empty vials containing a $6 \mathrm{~cm}$ strip of $3 \mathrm{M}$ Whatman filter paper to assist in moisture absorption. The vials were submerged into a water bath so that the bottom edge of the foam plug inside the vial was below the water line. After $30 \mathrm{~min}$, they were removed and the flies were transferred to food-containing vials. 572 transgenic flies, which induce less $28 \mathrm{kD}$ a protein than 807 , were induced using a $25^{\circ} \mathrm{C}$ to $37^{\circ} \mathrm{C}$ shift, while 807 transgenic flies were only shifted to $34^{\circ} \mathrm{C}$. All flies used for behavior were raised on a glucose-enriched food, while other flies were raised on a standard cornmeal/molasses medium.

Courtship conditioning. The training conditions used in this study have been described previously in the study by Sakai et al. (2004). Mated wild-type female flies were prepared $2 \mathrm{~h}$ before they were used to condition male flies. Three- to five-day-old virgin males were placed with a wild-type, premated female (3-5 d old) in a conditioning chamber ( 15 $\mathrm{mm}$ in diameter $\times 5 \mathrm{~mm}$ depth, made of transparent acrylic plastic) containing food for $5 \mathrm{~h}$. The chamber was either heat-shock induced, or not, for the entire $5 \mathrm{~h}$ period. Heat-shock induction consisted of an hour-long incubation at $28^{\circ} \mathrm{C}$, followed by $3 \mathrm{~h}$ at $30^{\circ} \mathrm{C}$ and a final hour at $28^{\circ} \mathrm{C}$. The nonheat shock incubation consisted of $22^{\circ} \mathrm{C}$ incubation for $5 \mathrm{~h}$ duration. The humidity for all flies was kept constant at $70 \%$. Following training (exposure to the mated female), the conditioned male flies were placed in food-containing vials at $22^{\circ} \mathrm{C}$ and $70 \%$ humidity until the time of testing, which occurred $15 \mathrm{~min}$ or $3 \mathrm{~d}$ after the end of training. For testing, a freeze-killed, 3-5-d-old virgin female was used as the target. All testing sessions lasted $10 \mathrm{~min}$ and were recorded using Logitech Portable Webcam C905. A blind observer scored courting behavior for each individual from the video. A courtship index (CI), defined as the percentage of time spent in courtship behaviors during the 10 min testing session, was calculated. In the untrained condition, a virgin male fly was placed in the conditioning chamber without a premated female fly and exposed to heat shock for $5 \mathrm{~h}$.

\section{Results}

Figure 1 shows the various open reading frames (ORFs) that are used in this report (see Materials and Methods for details). To determine what proteins are made off of various ORFs, including the one originally used for cellular and behavioral analyses (Yin et al., 1995a, b), different DNA templates are used for in vitro transcription, and the resulting mRNA is translated in rabbit reticulocyte extracts. The products are separated on Laemmli protein gels and visualized using autoradiography. The bottom panel of Figure $1 B$ shows that nearly equivalent amounts of mRNA were programmed into reticulocyte lysates for the different reactions. Therefore, the quantitative differences in protein levels are due to posttranscriptional processes, primarily translation initiation.

All of the different ORFs are capable of initiating translation at an intact ATG2 codon. In the absence of programmed mRNA (Lane 10), there is very little background protein produced. When 792 is used as the template for in vitro transcription, and 
the resulting mRNA is added to the reticulocyte extract, two prominent molecular species of $\sim 40$ and $28 \mathrm{kDa}$ (Lane 1) are produced. Mutating ATG1 on this template (792/DATG1, an ATG-to-ATT change, Lane 3), eliminates the $40 \mathrm{kDa}$ species, and increases the synthesis of the $28 \mathrm{kDa}$ one. Altering ATG2 (792/ $\Delta$ ATG2, an ATG-to-ATT substitution, Lane 2) eliminates the 28 $\mathrm{kDa}$ form. If both ATG1 and ATG2 are replaced with ATT (792/ $\Delta$ ATG1, 2, Lane 4), neither protein is made. These results indicate that the $40 \mathrm{kDa}$ protein initiates from ATG1, while the 28 $\mathrm{kDa}$ one starts from ATG2. When 572 is expressed in reticulocyte lysate, only the $28 \mathrm{kDa}$ protein is made (Lane 5), and mutation of ATG2 prevents its synthesis (572/DATG2, Lane 7), while removal of ATG1 (572/ $\Delta$ ATG1, Lane 6) has no effect. Therefore, the 572encoded $28 \mathrm{kDa}$ protein also initiates from ATG2. If a deletion is made that removes the sequences from ATG1 to just upstream of ATG2, thus forcing translation to start at ATG2 (807, Lane 8), there is high-level expression of a $28 \mathrm{kDa}$ protein. This protein starts from ATG2, since mutation of ATG2 (807 $\mathrm{ATG} 2$, Lane 9) inhibits its synthesis. Therefore, 792, 572, and 807 all produce an $\sim 28 \mathrm{kDa}$ protein, which initiates from ATG2.

To corroborate the in vitro expression analysis, epitope (FLAG)-tagged versions of various ORFs were placed in an expression vector downstream of the pActin promoter, and the plasmids are transfected and expressed in S2 cells. Western blots probed with a FLAG-specific antibody are used to assess protein expression, and the results are shown in Figure $1 C$. Transfection of the pActin blank vector produces low-level expression of nonspecific protein species due to antibody cross reactivity (Mock, Lane 1). When 792 is transfected, it expresses a protein isoform of $\sim 40 \mathrm{kDa}$ (labeled 40 [792], Lane 2). This species initiates from ATG1, since mutation of that codon (an ATG-to-CTG change) greatly diminishes its abundance (792/ $\Delta$ ATG1, Lane 3$)$. In addition, mutation of ATG1 unmasks the synthesis of a $28 \mathrm{kDa}$ protein band (labeled 28 [572/807], Lane 3). This $28 \mathrm{kDa}$ isoform initiates from ATG2, since mutation of that codon decreases its levels (Lanes 3 and 4). As expected, mutating both ATG1 and ATG2 (ATG-to-CTG substitutions) prevents expression of both proteins (792/DATG1, 2, Lane 5). These results show that the 40 and $28 \mathrm{kDa}$ species initiate from ATG1 and ATG2, respectively. When the 572 ORF is tagged and expressed, it makes a $28 \mathrm{kDa}$ protein band (572, Lane 6). This indicates that mRNAs that contain the upstream sequence rearrangement and (resulting stop codon) can still initiate translation from ATG2 in transfected cells. When 807 is transfected, it produces an identically sized 28 $\mathrm{kDa}$ protein (Lane 7). Therefore, whether the template is 792, 572 , or 807 , ATG2 can be used in reticulocyte lysate or transfected cells to generate a protein of $\sim 28 \mathrm{kDa}$. In both reticulocyte lysate and transfected cells, ATG1 (if present) is used to produce a 40 $\mathrm{kDa}$ protein. When both ATG1 and ATG2 are present, translation favors the usage of ATG1 in cells, while the lysate system is more promiscuous, and both proteins are made.

Historically, it has been difficult in fly extracts to detect the truncated protein that initiates from ATG2. However, a recently developed ATG2-specific antibody (see Materials and Methods) detects a protein whose mobility is consistent with translation initiation from ATG2. Figure $1 D$ shows Western analysis of total head extracts from wild-type ( $\mathrm{w}^{1118}$ iso [CJ1] referred to as $2202 \mathrm{U}$ or $2 \mathrm{U}$ ), 807, or 572 flies probed with this antibody. The top and middle panels were probed with this ATG2-specific antibody, and are different exposures of the same gel. In the top panel (short exposure), induction of 807 produces a prominent $28 \mathrm{kDa}$ species (see marker at left; Lane 4). Induction of 572 flies also produces a protein band of similar mobility, but visualiza- tion of this protein requires a longer exposure of the same section of the Western blot (Lane 6, long exposure, middle panel). The longer exposure also shows that there is an endogenous protein species of nearly identical mobility that appears in all lanes, including those from wild-type (nontransgenic; Lanes 1 and 2) and uninduced, transgenic flies (Lanes 3 and 5). The samples in each Lane on the blot are equivalent in levels, since reprobing this blot using the 657 (monoclonal) antibody produces equal levels of the $40 \mathrm{kDa}$ species (bottom panel). These data show that the $28 \mathrm{kDa}$ isoform is an endogenous dCREB2 protein species present at low basal levels in all flies, and that it is induced in both transgenic flies. It is likely that this protein initiates from ATG2 in all situations. Taken collectively, these data supports the conclusion that both 572 and 807 increase expression of a protein that is weakly present in all flies.

\section{Characterizing the ATG2-initiated protein}

The data in Figure 1 show unequivocally that translation initiation can begin at ATG2 in vitro, in transfected cells, and in transgenic flies, whether an upstream sequence rearrangement (and accompanying stop codon) exists or not. Could this protein be responsible for the behavioral enhancement that we originally reported? To answer these questions, it is necessary to determine whether the ATG2-initiated protein can function as a CREdependent transcriptional activator.

Figure $2 A$ shows the time course of 807 expression in extracts from transgenic flies. The induced protein is detectable $1 \mathrm{~h}$ after the end of heat-shock induction, and persists for at least $4 \mathrm{~h}$. We speculate that the induced $28 \mathrm{kDa}$ protein species may be modified over time, resulting in a protein that migrates above $30 \mathrm{kDa}$ (Lane 4).

Do the 572- and 807-encoded proteins bind CRE-containing DNA probes? Figure $2 B$ presents in vitro electrophoretic mobility shift assays (EMSAs or DNA gel shift reactions) using a CREcontaining probe and head extracts from wild-type or transgenic flies. For each of three flies (wild-type, transgenic 572 and 807), head extracts were analyzed using four different conditions [ +/induction and $+/-$ the $\alpha 657$ antibody included in the reaction (in a "supershift" experiment)]. The wild-type head extract contains probe-binding activity (Lane 2), and these complexes contain dCREB2 protein, since they are supershifted (have slower mobility) in the presence of the 657 antibody (compare Lanes 2 and 8). Binding activity increases for extracts from 572 and 807 flies in an induction-dependent manner (compare Lanes 3 with 6 for 572, Lanes 4 with 7 for 807). All of these complexes contain dCREB2 protein, since the complexes supershift in the presence of the antibody (Lanes 2-7 versus Lanes 8-13). Collectively, the data in Figures $1 D$ and $2 B$ support the conclusion that the 572 and 807 transgenic flies make identical proteins with nearly identical DNA binding activity, and the activity increases upon transgene induction. These data also shows that there is a very similar endogenous protein and DNA binding activity.

To extend this analysis one step further, the DNA-protein complexes are characterized using a larger scale version of an analytical protocol (Demczuk et al., 1993). The complexes are isolated from a preparative EMSA gel, the protein is allowed to elute from the gel slice and analyzed using Western blots probed with the $\alpha \mathrm{C} 21$ antibody. Figure 2C shows that the 807 elution contains a cluster of different dCREB2-specific protein bands in the $26-35 \mathrm{kDa}$ range, denoted with a bracket and an asterisk (Lane 3). In addition, the doublet (which contains the dCREB2-b blocker isoform) is also eluted from the gel fragment. The 572 eluate contains the most prominent bands that are detected in the 
A

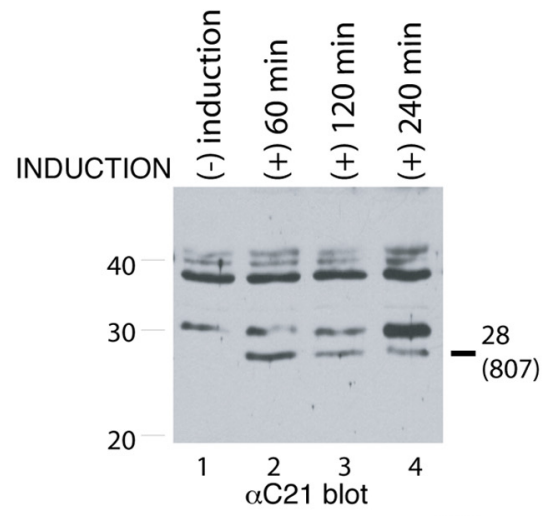

B
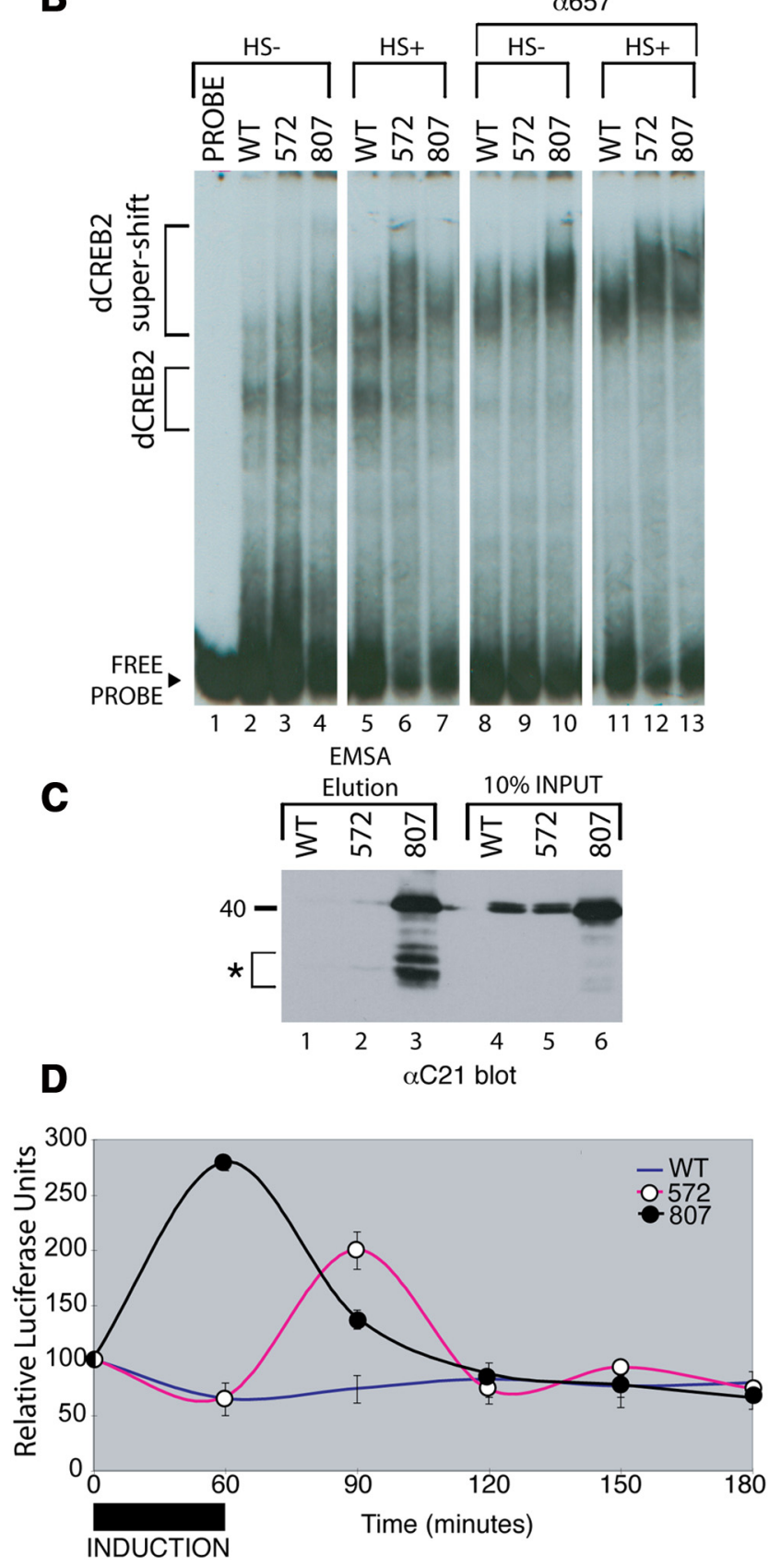

Figure 2. Induction of 807 and 572 produce a $28 \mathrm{kDa}$ protein with identical activities. $\boldsymbol{A}$, Time course of 807 inducible expression in head extracts. 807 transgenic flies are heat shock induced (room temperature to $37^{\circ} \mathrm{C}$ for $30^{\prime}$ ), or not, and equal amounts of total protein are separated using SDS PAGE. The proteins are transferred and probed using the $\alpha \mathrm{C} 21$ antibody. $\boldsymbol{B}$, The 572
807 fraction (Lane 2), but at significantly lower levels, while we cannot detect any bands in the wild-type eluate (Lane 1). Therefore, the DNA binding complexes found in the 572 and 807 extracts are very similar in their molecular content, and upon induction, contain more dCREB2-mediated binding activity than the wild-type extract.

The previous data show that 572 and 807 encode identical proteins that have very similar DNA binding properties. Do both of these transgenes make an activator protein? To answer this question, we use the previously described CRE-luciferase transgenic fly, a reporter of CRE- and dCREB2-dependent transcription (Belvin et al., 1999). The 572 and 807 transgenes, as well as the wild-type control, are crossed into the CRE-luciferase fly to test the function of the transgene-encoded proteins. The transgenes are induced $\left(25^{\circ} \mathrm{C}\right.$ to $37^{\circ} \mathrm{C}$ temperature shift for $\left.30^{\prime}\right)$, or not, and luciferase activity is measured in vitro.

Figure $2 D$ shows transcription activity plotted as a function of time. There is an increase in luciferase activity for both 572 and 807 beginning almost immediately after the end of the heatshock, but the kinetics of this activation differ. The 807 transgene shows a faster and greater increase in the amount of stimulation. However, all increases in luciferase are short-lived, with the 807 peak lasting $\sim 120^{\prime}$ maximum, and the 572-mediated increase persisting for $\sim 60^{\prime}$. The short-lived increase in activity is surprising, since the induced 807 protein appears to be stable for many hours (Fig. 2A). This "permissive interval" for transcriptional activation of 572 is even shorter-lived. The data in Figure $2 A-D$ show that 807 and 572 express identical proteins, that these proteins bind CRE sites in a nearly identical manner, and that they function as transcriptional activators in vivo. Therefore, these transgenes are essentially identical except that 807 produces more activator protein when induced.

\section{Endogenous dCREB2 activator}

The induced protein band in 572 and 807 transgenic flies has a similar mobility to an endogenous $28 \mathrm{kDa}$ "background" band that is recognized using a dCREB2-specific antibody (Fig. 1D). To determine whether this endogenous band is made from dCREB2, different dCREB2-specific antibodies were used for immune-precipitation experiments from wild-type head extracts.

Figure $3 A$ shows that wild-type head extracts contain a $28 \mathrm{kDa}$ dCREB2-encoded protein species. When a wild-type head extract is compared with one from S162 flies, a number of unique protein species are visualized, including the doublet that migrates $\sim 40$ $\mathrm{kDa}$, and a cluster of protein bands that migrate in the $22-35 \mathrm{kDa}$ range. These are all absent in the S162 mutation, since it contains a stop codon in the dCREB2 ORF (Hendricks et al., 2001). Strip-

\footnotetext{
$\leftarrow$

and 807 transgenic flies increase dCREB2-containing CRE-binding activity in an inductiondependent manner. Head extracts are made from wild-type, 572, or 807 transgenic flies that are heat shock induced ( $\mathrm{HS}+$ ), or not (HS-), and equivalent amounts of protein are used in EMSA assays using a radioactive (RE-containing probe. The addition of the $\alpha 657$ (monoclonal) antibody produces supershifted complexes. C, The EMSA protein complexes from 572 and 807 extracts contain the $28 \mathrm{kDa}$ dCREB2 band. The $\alpha \mathrm{C} 21$ antibody is used for Western analysis of EMSA complexes that are excised from a preparative gel, eluted, and rerun using SDS PAGE. $\boldsymbol{D}$ Both the 572 and 807 transgenes transiently activate a CRE-luciferase reporter in vivo. The time course of luciferase activity for progeny flies when wild-type, 572 , and 807 flies are crossed with the CRE-luciferase reporter fly, heat-shock induced (INDUCTION), and assayed biochemically is shown. All of the progeny flies contain a single copy of the CRE-luciferase transgene, and either no other transgene (WT), or one copy of 572 or 807 . Statistical significance of the dataset was determined via two-way ANOVA, with a $p<0.001$.
} 

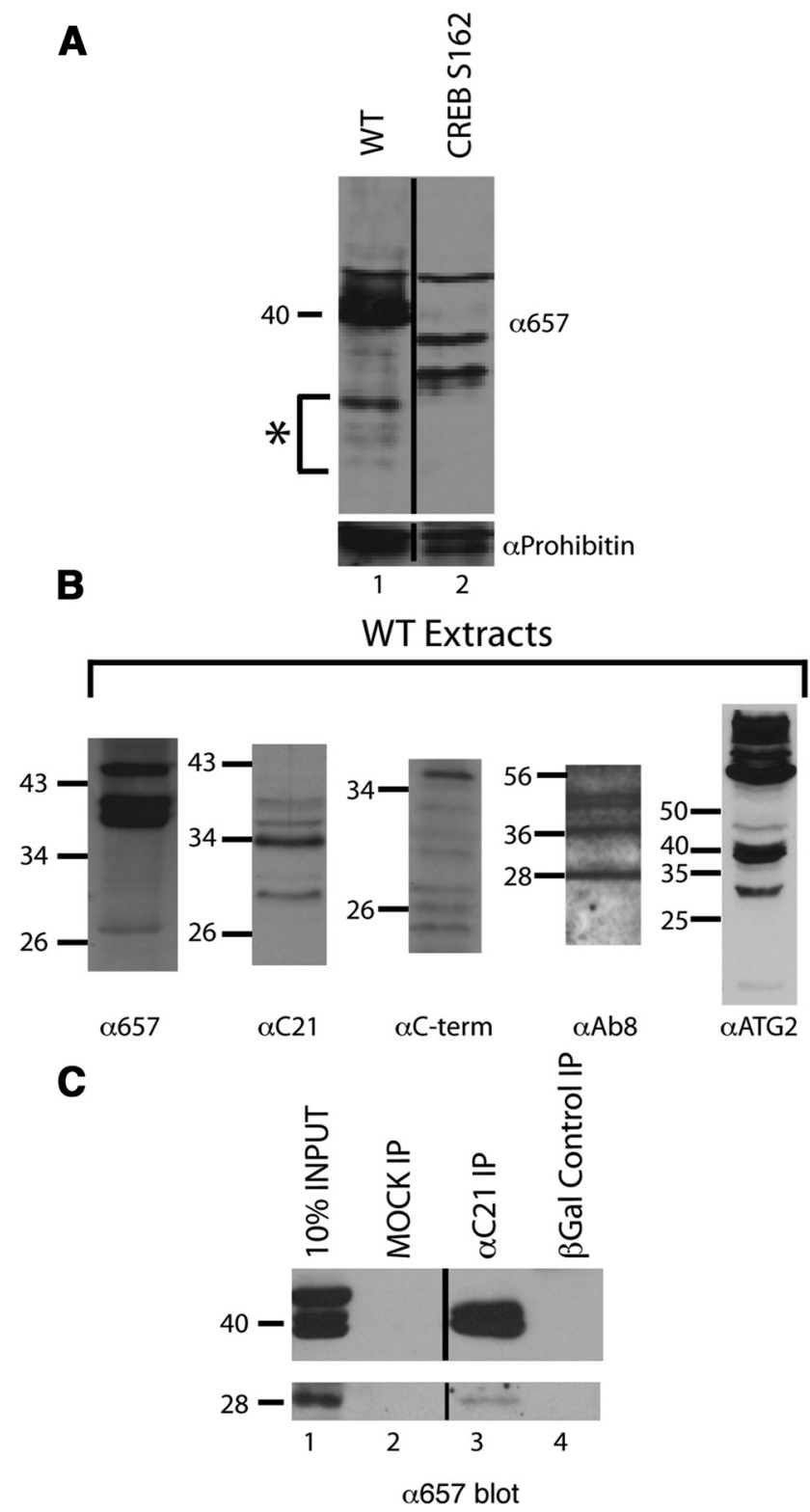

Figure 3. Wild-type flies contain an endogenous $28 \mathrm{kDa}$ protein. $\boldsymbol{A}$, A cluster of protein bands, including the $28 \mathrm{kDa}$ isoform, are missing in the dCREB2 mutant S162. Western blot analysis of head extracts from wild-type (2U) and the CREB-null mutant, S162, indicates a loss of the $28 \mathrm{kDa}$ CREB isoform (*). For each line, $30 \mu \mathrm{g}$ of head extracts were fractionated on a $12 \%$ SDS-PAGE gel, blotted onto a nitrocellulose membrane, and probed with $\alpha$ CREB657 monoclonal antibody. $\alpha$ Prohibitin antibody was used at 1:50 to monitor total protein content in each sample. $\boldsymbol{B}$, Multiple antibodies recognize a $28 \mathrm{kDa}$ protein band in extracts from wild-type flies. Western blot analysis of equivalent amounts of protein from wild-type flies probed with different antibodies. C, The $\alpha \mathrm{C} 21$ antibody immunoprecipitates a $28 \mathrm{kDa}$ protein from wild-type head extracts. Blank (MOCK IP), $\alpha(21$, or a control ( $\beta$-galactosidase) antibody is used for immunoprecipitation reactions from equivalent amounts of total adult head protein. Immunoprecipitates are reseparated using SDS PAGE and Western blotted using the $\alpha 657$ antibody.

ping and reprobing these blots with $\alpha$-prohibitin antibody shows that equivalent amounts of protein are on the two blots, validating quantitative comparisons between them. The S162 extract does contain some truncated protein species, presumably due to the stop codon located at the C-terminal part of the dCREB2encoded proteins (Hendricks et al., 2001). Figure $3 B$ shows that multiple, different, dCREB2-specific antibodies recognize some of the same faster migrating species that the $\alpha 657$ antibody detects. This immunological data supports the analysis using
S162 extracts showing that some or all of these species are dCREB2-specific.

To positively identify at least one of these species, the $\alpha \mathrm{C} 21$ antibody is used to immunoprecipitate protein out of wild-type head extracts. Protein species in the immune-precipitate are separated using Laemmli gels, and revisualized using the dCREB2specific monoclonal antibody. Figure $3 C$ shows that $\alpha 657$ recognizes a small protein band of $\sim 28 \mathrm{kDa}$ in the immune-precipitation reaction (Lane 3), in addition to the $40 \mathrm{kDa}$ doublet. These species are all absent in a control immune-precipitation performed with an antibody directed against the $\beta$-galactosidase protein (Lane 4 ). Together, the data in Figures $1 D, 2 C$, and $3 A-C 3$ demonstrate that 792, 572,807 , and the endogenous chromosome all make a $28 \mathrm{kDa}$ protein that initiates from ATG2 that binds to CRE sequences (Fig. $2 B-D)$.

Another way to assess the importance of ATG2 as an initiation codon is to ask whether it is conserved across different Drosophila species. We analyzed seven of the available genomic sequences, and based on our knowledge of dCREB2 in Drosophila melanogaster, assembled a comparison of the ORFs of the various CREB genes. For simplicity, we have omitted the alternatively spliced exon 2, which is not present in all species (data not shown). Figure $4 A$ shows this comparison. While there are notable regions of total or near total identity (the KID domain in exon 5, the bZIP domains in exon 7), exons 1, 3, and 6 are not as highly conserved. However, ATG2, which resides in exon 3 and is marked with an asterisk, is totally conserved. Figure $4 B$ shows the phylogenetic tree of these Drosophila species, where the two most distant species, D. melanogaster and D. grimshawi, remain highly conserved at the level of amino acid sequence identity (69\%) and homology (73\%). These Drosophila species are tens of millions of years apart, yet ATG2 is conserved across all of them, arguing for the importance of ATG2.

Is the ATG2 codon functionally conserved across these different species? If so, then the different species should make proteins that migrate $\sim 28 \mathrm{kDa}$, since the length and composition of the $\mathrm{dCREB}$ proteins from the various species is almost identical. Figure $4 C$ shows a Western blot of head extract protein from a number of different species probed with the $\alpha \mathrm{C} 21$. Both the $40 \mathrm{kDa}$ doublet species, which correspond to the dCREB2-a (792) and dCREB2-b protein isoforms, as well as species near $28 \mathrm{kDa}$, are present. Thus, all of these different species are likely to use the ATG2 initiation codon, arguing for its importance through evolution.

\section{Factors that influence memory enhancement}

A few years after the publication of our original study describing memory enhancement, it became increasingly clear that memory enhancement was somewhat stochastic. Once the role of ATG2 became clear, we made the simplest hypothesis that variable enhancement was due to inconsistent protein induction, since translation reinitiation is an inefficient process. The 572 (rearranged) transgene always produces less protein than 807 (Fig. $1 B-D)$, and it is possible that its induced levels are variable from experiment to experiment, and not always above a threshold quantity to enhance memory formation. However, enhancement using the 807 transgene is also inconsistent (data not shown), despite its consistent high level of protein production.

A related possibility is that the half-life of activity of the induced protein is variable, sometimes lasting long enough to enhance memory formation, but other times not. Our reporter experiments (Fig. 2D) show that the "permissive interval" during which the induced protein activates transcription is much shorter 

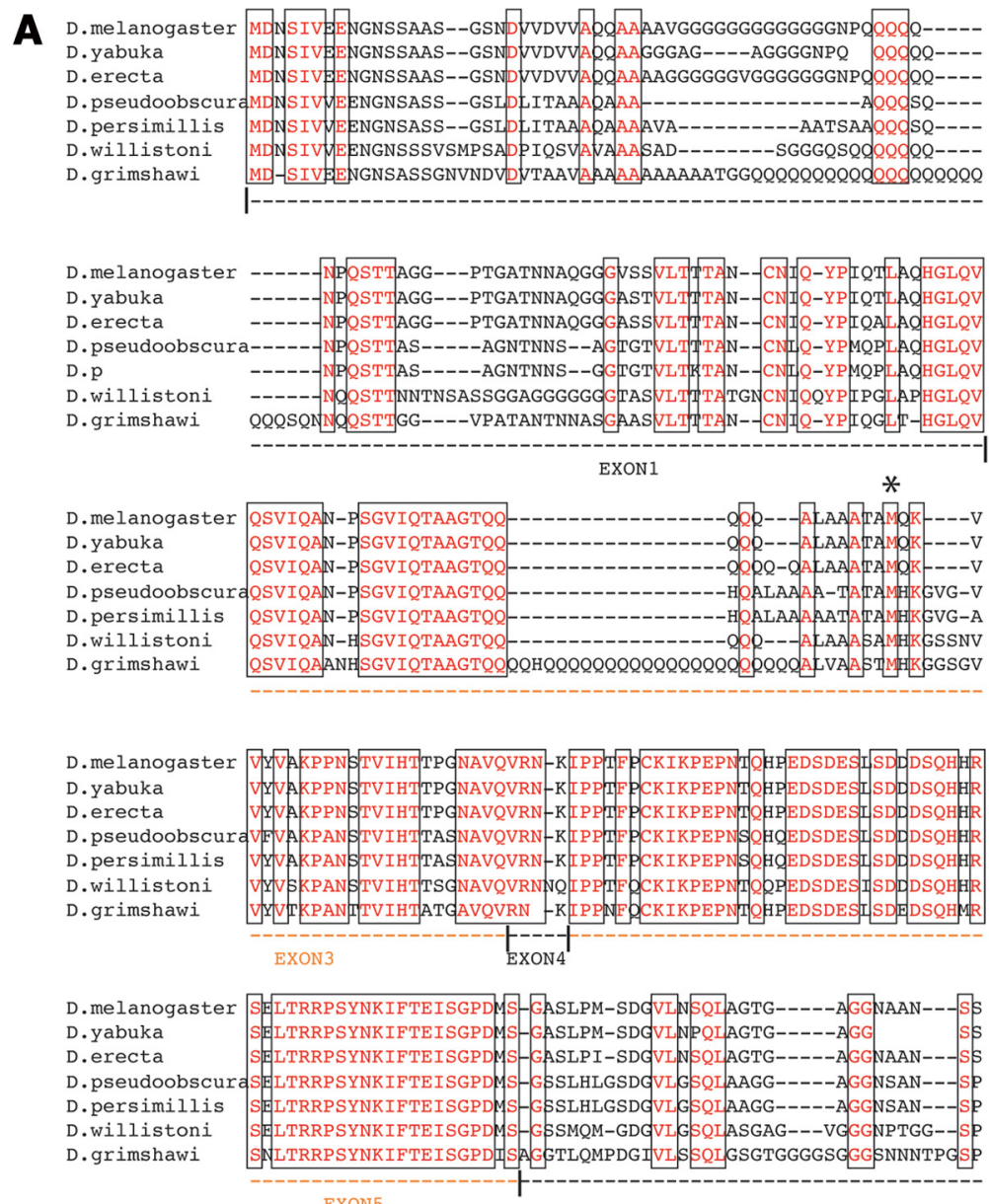

$$
\text { EXON5 }
$$

D. melanogaster TMOLD--PTYYL-SNRMSY YNTNSGIAEDOTRKRE IRLOKNREAARECRRKKKEYIKCLE D. yabuka IMQLD--PTYYL-SNRMS YNT NNSGIVEDOTRKREIRLQKNREAARECRRKKKEY IKCLE D.erecta IMQLD--TTYYL-SNRMS YNSNNSGIAEDQTRKREIRLQKNREAARECRRKKKEYIKCLE D. pseudoobscura LHMAPEPAYYL-SNR IPYNT NNSG IAEDOTRKREIRLQKNREAARECRRKKKEY IKCL D persimillis THMAPDAYYY -SNRTPYNT D.willistoni LLHMGPESAYYI-SNRIAYQT NNSGIAEDQSARKREIRLQKNREAARECRRKKKEYIKCL D.grimshawi ЧLHMAPDPAFYLPSNIAYNTINSGIAEDOTI KROLRLOKNREAARECRRKKKEYIKCLE EXON6
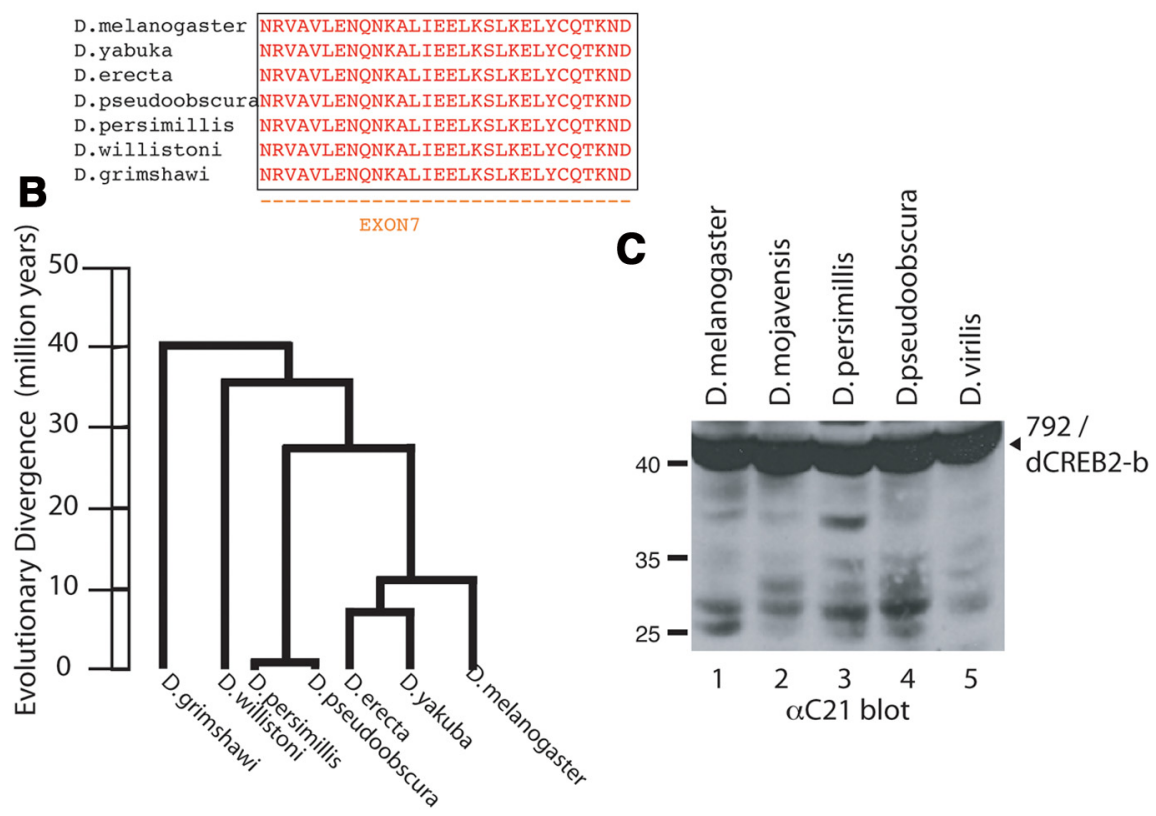

Figure 4. The ATG2 codon is conserved and functional across Drosophila species. $A$, The ATG2 codon is conserved across Drosophila species. Sequence alignment of dCREB2 genes from different species. $\boldsymbol{B}$, Evolutionary conservation between Drosophila than the persistence of the protein itself (Fig. 2, compare $A, D$ ). A related, but more complicated possibility is that the window of activity for other signaling pathways that are needed for memory formation is complex (Philips et al., 2007; Liu et al., 2011). To test these hypotheses, we systematically varied the interval between the end of transgene induction and the beginning of behavioral training (the "temporal window"). Different groups of 807 transgenic flies were induced, or not, allowed to recover for varying amounts of time, trained, and tested for $1 \mathrm{~d}$ memory. Figure $5 \mathrm{~A}$ shows the results of this titration. Uninduced 807 flies do not have significant $1 \mathrm{~d}$ memory after three cycles of massed training. However, there is a temporal window $\left(60-120^{\prime}\right)$ during which behavioral training can use the induced protein and produce $1 \mathrm{~d}$ memory. Intervals shorter than $60^{\prime}$, or longer than $120^{\prime}$, do not result in enhancement of $1 \mathrm{~d}$ memory. Although we have not systematically optimized the temporal window for the 572 transgene, the $90^{\prime}$ interval that works for 807 also can result in C28-mediated enhancement of $1 \mathrm{~d}$ memory (Fig. $5 B$ ). C28 is the name of the original 572 line used for behavioral enhancement. These results show a correlation between the permissive interval for transcription and a temporal window for behavioral enhancement, and suggest that under certain experimental conditions, the timing between the end of induction and the beginning of behavioral training can influence enhancement.

dCREB2 transcriptional activity has been shown to be under the control of the circadian system, with peaks of in vivo activity during the daytime and early nighttime (Belvin et al., 1999). Therefore, it is possible that the natural oscillation in dCREB2 activity affects memory enhancement, since training time is not usually carefully controlled. If either of two 807 transgenes $(1 \mathrm{M}$ or $2 \mathrm{M})$ are induced at $\mathrm{ZT}=11$, and the flies are trained with three cycles of massed training at $\mathrm{ZT}=13$, there is behavioral enhancement that produces $4 \mathrm{~d}$ memory (Fig. 6A). Induction of the same transgenes at ZT $=6$ does not enhance memory formation. Memory enhancement can also occur if flies only receive a single training trial, recapitulating our original results (Fig. $6 B$ ). These data

species (C) The $28 \mathrm{kDa}$ band is detectable in other Drosophila species. Western blot analysis of head extracts from different Drosophila species using the $\alpha \mathrm{C} 21$ antibody. 
A 35

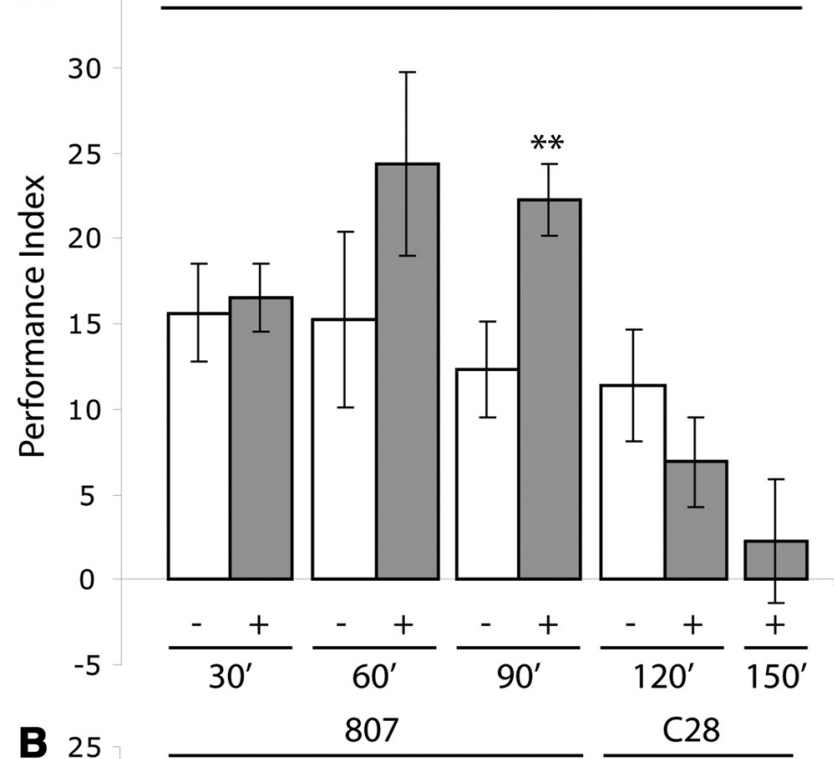

B 25

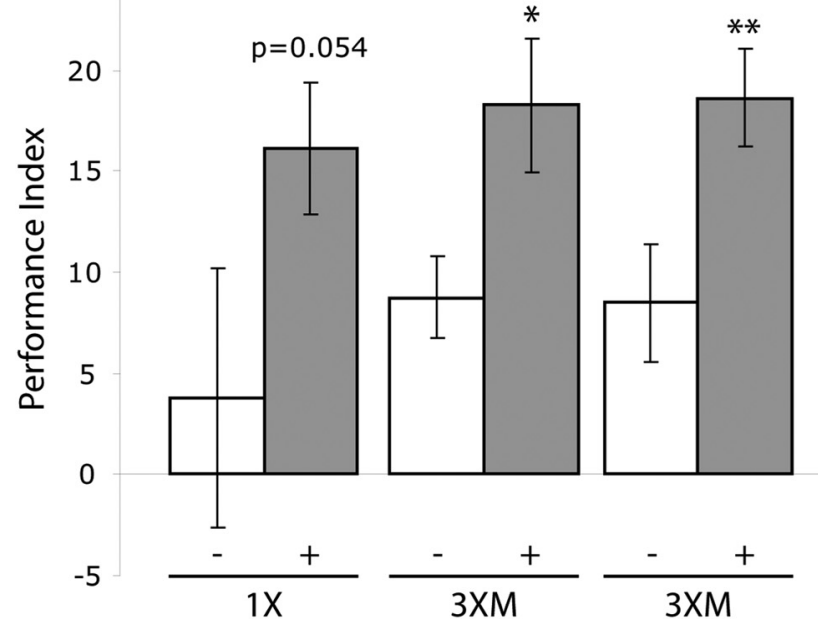

Figure 5. A temporal window constrains memory enhancement. $A, 807$-mediated memory enhancement has a temporal window. Different groups of 807 transgenic flies are heat shock $\left(25^{\circ} \mathrm{C}\right.$ to $34^{\circ} \mathrm{C}$ for $\left.30^{\prime}\right)$ induced $(+)$, or not $(-)$, transferred to food-containing vials, and allowed to recover for varying amounts of time (shown on the $x$-axis), trained with 3 cycles of massed training $(3 \times M)$, then returned to food-containing vials, and tested for $24 \mathrm{~h}$ memory. Error bars represent $\mathrm{SEM}$, and the asterisk indicates statistical significance $\left({ }^{* *} p<0.01\right)$ using Student's $t$ test. $N=8$ for all groups, except $+/-H S 30^{\prime}$, and $+/-H S 90^{\prime}$, for which $N=16$. $B, 572$ - and 807-mediated memory enhancement. Transgenic 572 (the original ( 28 line) or 807 flies are heat-shock induced $(+)$, or not $(-)$, allowed to recover for $90^{\prime}$, trained with a single cycle of training $(1 \times)$, or 3 cycles of massed training $(3 \times M)$, and tested for $24 \mathrm{~h}$ memory. To equalize induced expression, the 807 flies are induced using a weaker heat-shock regimen $\left(25^{\circ} \mathrm{C}\right.$ to $34^{\circ} \mathrm{C}$ for $\left.30^{\prime}\right)$ than the one used for the $572(\mathrm{C} 28)$ line $\left(25^{\circ} \mathrm{C}\right.$ to $37^{\circ} \mathrm{C}$ for $\left.30^{\prime}\right)$. Error bars represent SEM, and the asterisk indicates statistical significance $\left({ }^{*} p<0.05,{ }^{* *} p<0.01\right)$ using Student's $t$ test. $N=8$ for all groups.

show that the time of behavioral training is another parameter that can influence enhancement of memory formation.

To test whether behavioral enhancement is dependent upon ATG2, we have changed this codon to ATT, and made heat-shock inducible transgenic flies (referred to as $\triangle \mathrm{ATG} 2$ ). Figure $6 \mathrm{C}$ shows that the 807 transgene produces robust $24 \mathrm{~h}$ memory while the mutant transgene does not. Inducing the transgene, or not, does not affect the task-relevant peripheral controls, olfactory acuity, and shock reactivity (data not shown). Therefore, the effect on memory is attributable to the association of odor and shock, and not their perception. We have compared the levels of RT-PCR amplified products from wild-type, 807, and $\triangle$ ATG2 transgenic flies. Since detection of the RT-PCR product requires reverse transcription before PCR amplification (compare Lanes $1-6$ vs 7-12), the amplified products result from RNA amplification rather than from contaminating chromosomal DNA. Figure $6 D$ shows that extracts from both induced transgenes result in roughly equivalent amounts of amplified product (compare Lanes 8 and 10), implying that they had similar amounts of starting mRNA template. The uninduced transgenic extracts (Lanes 7 and 9), as well as the wild-type extracts (Lanes 11 and 12) show a similar, very low level of amplified product. These presumably represent the levels of amplifiable mRNA that is made from the endogenous dCREB2 locus. These data supports the conclusion that the differences in protein levels between induced 807 and induced $\triangle \mathrm{ATG} 2$ is likely attributable to differences in the efficiency of translation initiation.

\section{Enhancement of courtship suppression}

To further demonstrate the ability of the ATG2-initiated protein to enhance memory formation, we turned to another behavioral assay. Experience-dependent courtship suppression is a well established paradigm used to assess learning and memory in Drosophila (Ejima and Griffith, 2011). Upon exposure to a virgin female fly, naive males display a series of complex, stereotypical behaviors that lead to mating. Virgin females respond by mating, but premated females will not be receptive, displaying a different repertoire of behaviors and emitting a different pheromonal profile. A virgin male exposed to a premated female for $1 \mathrm{~h}$ ("training") will display suppressed courtship behavior when placed with a naive female ("testing") up to $3 \mathrm{~h}$ after training (Siegel and Hall, 1979). The exposure time between the naive male and premated female can be modulated to produce shorter or longerlasting memories.

Naive males were placed with premated females for $5 \mathrm{~h}$, and tested for $3 \mathrm{~d}$ memory using naive females (Sakai et al., 2004). The $\mathrm{CI}$ is defined as the fraction of time the male engages in courting behaviors during the testing period. Higher CI values correspond to increased courting behavior, and therefore represent poor memory for prior training, whereas a low $\mathrm{CI}$ indicates courtship suppression and enduring memory of the training.

When a control transgenic fly is induced, or not, its courtship index $3 \mathrm{~d}$ after training is very high, consistent with poor memory (Fig. 7A). This fly contains a transgene that is unrelated to dCREB2 protein production, but is made in the same genetic background. When the 807 transgene is induced during training, courtship suppression is very strong $3 \mathrm{~d}$ after training, consistent with enhanced memory. Its courtship index is significantly lower (better memory) than the performance in uninduced 807 flies, or in control flies whether induced or not. To show that this effect occurs on memory formation and not learning, we assessed the courtship index immediately after the end of training (Fig. $7 B$ ). Whether the 807 transgene is induced, or not, flies show strong courtship suppression when assayed immediately after training, and there is no statistically significant difference between these two treatments. This immediate learning is training-dependent, since a control, untrained (but induced) 807 group does not show any immediate suppression. Together, these data suggest that the induction-dependent effect of 807 on $3 \mathrm{~d}$ memory is not due to an effect on learning. Finally, to show that enhancement requires protein that initiates from ATG2, we assayed courtship suppression in 807 versus $\triangle \mathrm{ATG} 2$ transgenic flies. The data in Figure $7 \mathrm{C}$ show that in the $807 \mathrm{fly}$, there is induction-and training- 
A

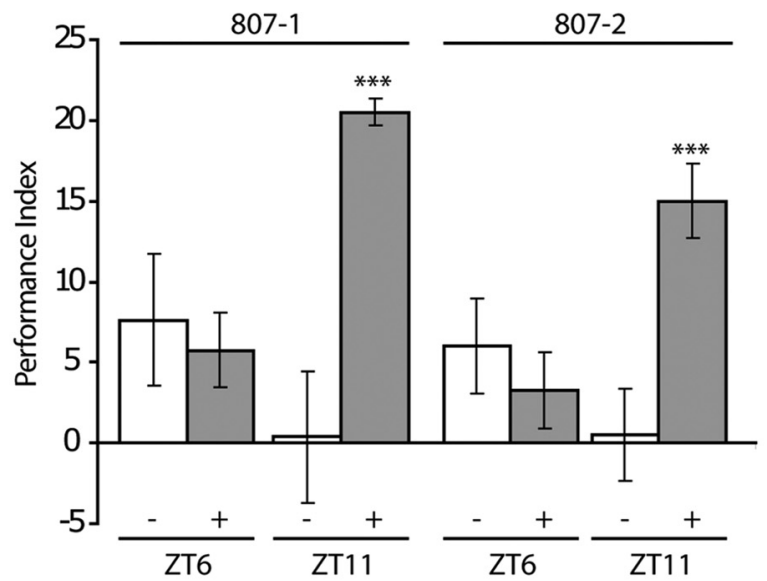

B

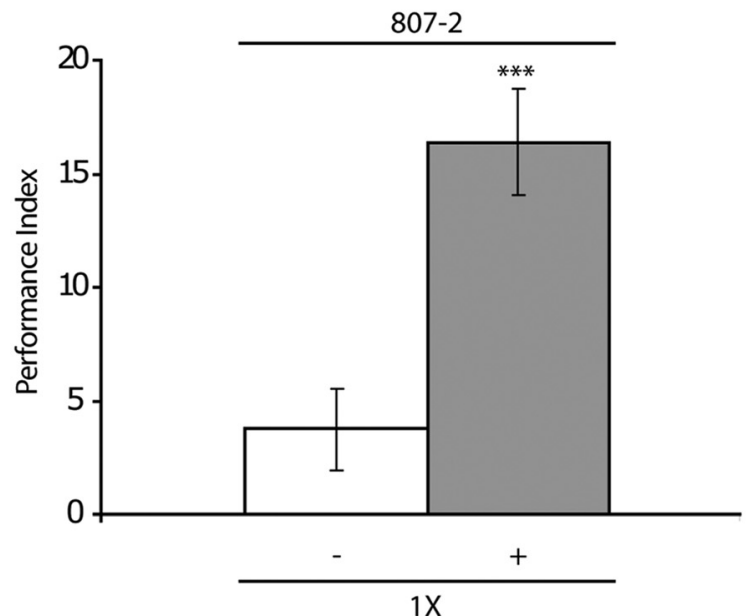

C

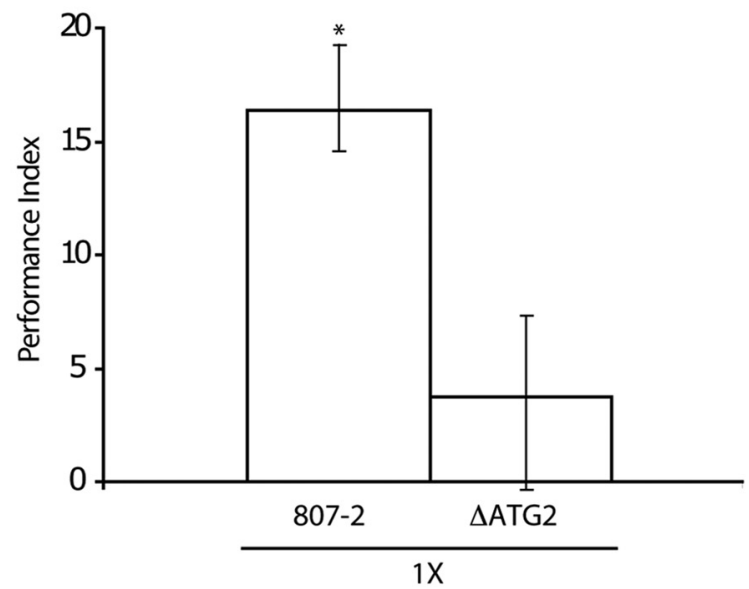

D

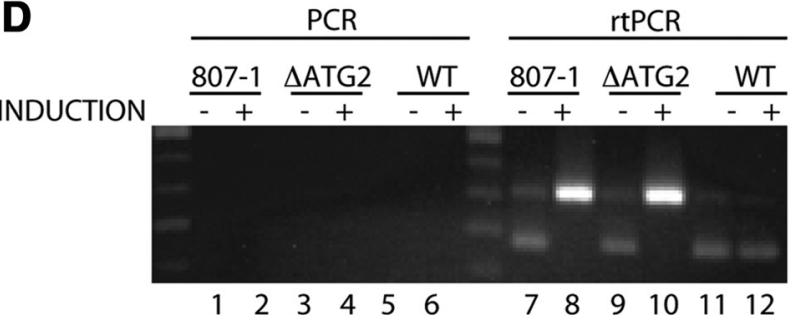

Figure 6. The time of day affects memory enhancement. $\boldsymbol{A}$, The time of induction and training affect memory enhancement. Transgenic flies carrying either of two independent insertions of 807 (Lines 1 and 2) are entrained on a strict 12/12 h light/dark schedule. Different groups of flies are heat shock induced $(+)$, or not $(-)$ for $30^{\prime}\left(25\right.$ to $\left.34^{\circ} \mathrm{C}\right)$ beginning at either $Z \mathrm{~T}=6$ or $\mathrm{ZT}=11$, allowed to recover for $90^{\prime}$, trained with 3 cycles of massed training, returned to circadian cycling conditions, and tested for $4 \mathrm{~d}$ memory. Since heat shock lasts $30 \mathrm{~min}$, and the

dependent enhancement of courtship suppression that requires ATG2. Repeated experiments using this assay produce similar results, showing that enhancement is consistent (data not shown).

Taken all together, our molecular and behavioral data show that the original 572 transgene encodes a short protein which is able to enhance memory formation. The 807 transgene produces an identical protein, and both of these proteins are transcriptional activators. Most importantly, induction of 807 enhances memory formation using both the olfactory avoidance and courtship suppression assays.

\section{Discussion}

For many years, we have focused on two questions. What is the identity of the molecule that allows 572 to enhance memory formation? Why is behavioral enhancement inconsistent? In this report, we have shown that a $28 \mathrm{kDa}$ protein initiates from the internal ATG2 codon, that it functions as a CRE-dependent transcriptional activator both in vitro and in vivo, and is responsible for our original report of memory enhancement. Although ATG2 is infrequently used, and the resulting protein is expressed at low levels, its existence has been shown using multiple antibodies and different two-step enrichments (EMSA supershifts and Western identification of proteins on EMSA complexes).

The ATG2 codon is also used on endogenous dCREB2encoded mRNAs, since all of the sequenced dCREB2 cDNAs contain ATG1 and ATG2 on the same molecule (Yin et al., 1995b). Interestingly, internal translation initiation is also used on both of the mammalian CREM (Delmas et al., 1992) and CREB genes. "Intronic" or internal ATGs can become positioned to be the first start codons through alternative promoter usage and alternative splicing. The mammalian CREB $\beta$ isoform is a minority species that becomes upregulated upon deletion of the $\alpha$ and $\Delta$ isoforms (Blendy et al., 1996). We have not characterized the transcriptional regulation of the dCREB2 gene, so it is possible that ATG2 is the first initiation codon on a minor, currently uncharacterized, dCREB2 transcript.

A number of related issues have complicated molecular analysis of dCREB2-encoded protein isoforms, and are likely to be relevant in the characterization of these proteins in all species. First, the number and variety of posttranslational modifications that occur on dCREB2-encoded proteins is large. The KID region contains up to 7 phosphorylation sites, and other modifications, including O-GlcNac glycosylation, SUMOylation, ubiquityla-

\footnotetext{
$\leftarrow$

flies are allowed to recover for $90 \mathrm{~min}$, training begins at either $Z T=8$ or $Z T=13$. Error bars represent SEM, and the asterisk indicates statistical significance $\left.{ }^{* * *} p<0.001\right)$ using Student's $t$ test. $N=8$ for all groups. $\boldsymbol{B}$, Memory enhancement can result after a single cycle of training. Transgenic 807 flies (Line 2) are entrained on a strict 12/12 h light/dark schedule. Different groups of flies are heat shock induced $(+)$, or not $(-)$, for $30^{\prime}\left(25\right.$ to $\left.34^{\circ} \mathrm{C}\right)$ beginning at $Z T=$ 11 , allowed to recover for $90^{\prime}$, trained with a single cycle of training $(1 \times)$, and tested for $4 \mathrm{~d}$ memory. Error bars represent SEM, and the asterisk indicates statistical significance ${ }^{* * *} p<$ 0.001 ) using Student's $t$ test. $N=8$ for all groups. $C$, Memory enhancement is ATG2-dependent Transgenic 807 (Line 2) and $\Delta$ ATG2 flies are entrained on a strict 12/12 h light/dark schedule. Flies are heat shock induced $(+)$ for $30^{\prime}\left(25\right.$ to $\left.34^{\circ} \mathrm{C}\right)$ beginning at $Z T=11$, allowed to recover for $90^{\prime}$, trained with a single cycle of training $(1 \times)$, and tested for $1 \mathrm{~d}$ memory. Error bars represent SEM, and the asterisk indicates statistical significance $\left({ }^{*} p<0.05\right)$ using Student's $t$ test. $N=8$ for all groups. $D$, The 807 and $\triangle$ ATG2 transgenic flies induce equivalent amounts of dCREB2 mRNA. Total head RNA is collected from three different flies (807, $\triangle$ ATG2 or wild-type) that were exposed to one of two treatments [heat shock induction $(+)$ or not $(-)$ ]. Each individual sample (of the 12 total) underwent RT-PCR (Lanes 7-12) or PCR only (Lanes 1-6), and the products were separated on an agarose gel and visualized using ethidium bromide staining.
} 


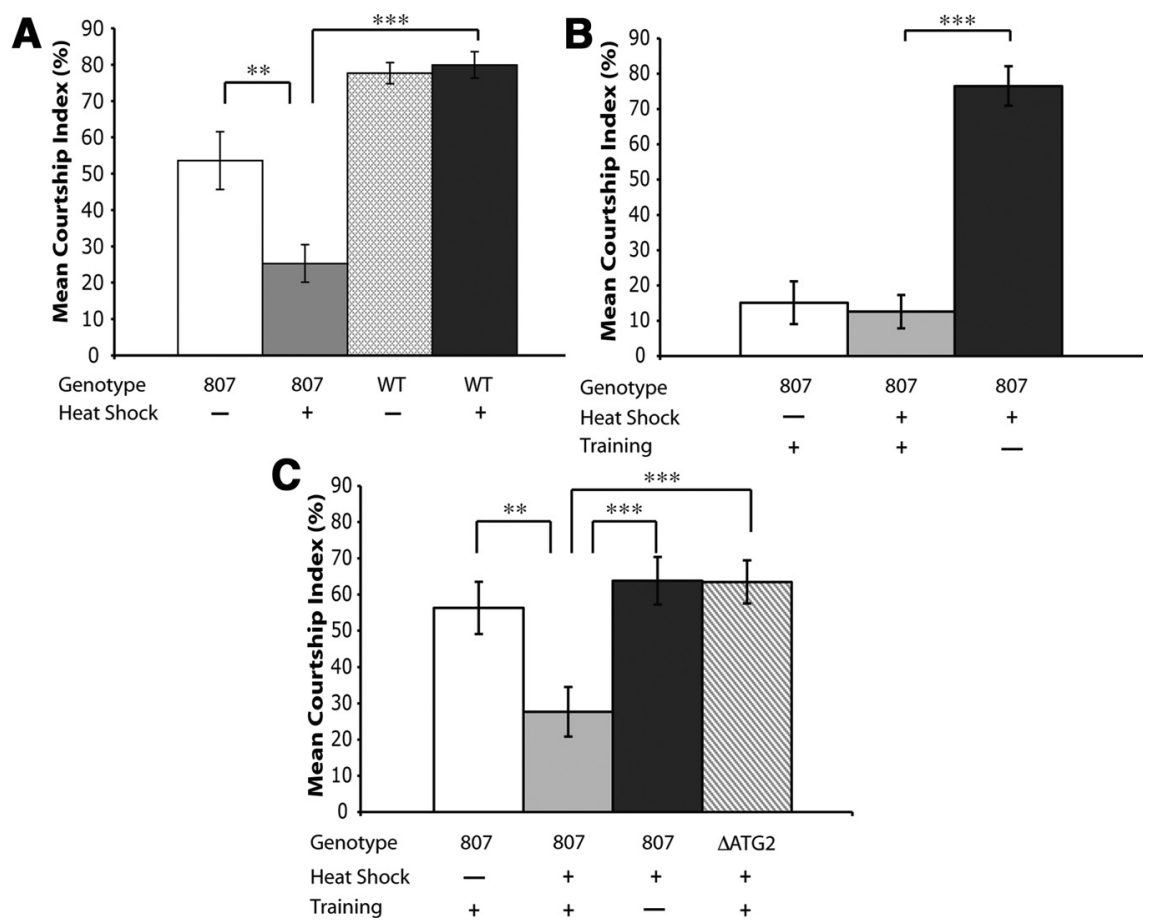

Figure 7. Induction of 807 enhances memory of suppression of courtship conditioning. $A, 807$-mediated memory enhancement is induction-dependent. Mean courtship index $3 \mathrm{~d}$ following training of 807 and wild-type (WT) flies heat shock induced (+) or not $(-)$. Left to right: open column represents uninduced 807 flies $(N=25)$; gray column represents heat shock induced 807 flies $(N=33)$; stippled column represents uninduced wild-type flies $(N=33)$; black column represents heat shock induced wild-type flies $(N=35)$. $\boldsymbol{B}$, Transgene induction does not affect immediate performance after training (learning). Mean courtship index for 807 flies exposed to different induction and training conditions. Testing occurred $15 \mathrm{~min}$ following $5 \mathrm{~h}$ of courtship training. Left to right: open column represents uninduced but trained 807 flies $(N=14)$; gray column represents heat shock induced and trained flies $(N=19)$; black column represents untrained but heat shock induced 807 flies $(N=27)$. C, Memory enhancement is induction-, training-, and ATG2-dependent. Mean courtship index $3 \mathrm{~d}$ following $5 \mathrm{~h}$ of training in both 807 and ATG-2 flies exposed to different HS and training conditions. Left to right: open column represents uninduced and trained 807 flies $(N=16)$; gray column represents heat shock induced and trained 807 flies $(N=27)$; black column represents heat shock induced but not trained 807 flies $(N=23)$, and stippled column represents heat shock induced and trained $\triangle A T G 2$ flies $(N=26)$. In all figures, ${ }^{* *} p<0.005 ;{ }^{* * *} p<0.001$, and error bars show SEM. Since the mean courtship index was not distributed normally, the data were analyzed using the Mann-Whitney $U$ test in the Sigma Stat statistical software package (Systat Software).

tion, and cysteine oxidation and/or nitrosylation, occur elsewhere on CREB proteins (Gonzalez et al., 1989; Goren et al., 2001; Comerford et al., 2003; Lamarre-Vincent and HsiehWilson, 2003; Riccio et al., 2006). These posttranslational modifications can dramatically affect the apparent mobility of protein species, and make it difficult to determine whether Western blots that contain many bands are due to a nonspecific or specific recognition of dCREB2-encoded proteins. A related observation is that these modifications can alter the binding affinity of many of our antibodies ( $\mathrm{T}$. Tubon, unpublished observations), suggesting that any given antibody reports a specialized subpool of protein. Finally, the blocker ( $40 \mathrm{kDa}$ doublet) and activator (22-35 $\mathrm{kDa}$ cluster) species seem to be differentially modified ( $\mathrm{T}$. Tubon, unpublished observations), further complicating detailed analysis. It is likely that combinations of modifications are used to regulate the complex subcellular localization and activity of dCREB2 protein isoforms.

Various parameters contribute to the inconsistency of memory enhancement. The expression of the $28 \mathrm{kDa}$ protein off of the original 572 transgene is low but detectable. However, this modest level of expression is not responsible for inconsistent enhancement of olfactory avoidance memory, since the 807 transgenic fly (which has consistently higher levels of expression) also sporadically enhances memory formation. Instead, the limited duration of dCREB2-mediated transcriptional activation can place serious timing constraints on the requisite interval between transgene induction and behavioral training (the temporal window). A second temporal parameter is the time-of-day when induction and behavioral training occur. There is a growing awareness that the timeof-day of training can affect memory formation, and this literature highlights the importance of circadian/sleep-related physiological processes and their relationship with the neuroanatomy and molecular machinery of memory formation (Fernandez et al., 2003; Chaudhury et al., 2005; Lyons et al., 2005; Lyons et al., 2006, Ruby et al., 2008, Eckel-Mahan et al., 2008). Careful control of these different timing issues greatly increases the reproducibility of behavioral enhancement using the olfactory avoidance assay. The consistent enhancement of the courtship behavior reinforces the original observation that the $28 \mathrm{kDa}$ protein can enhance memory formation.

Why does 807 enhance memory of courtship suppression reliably, but affects memory of olfactory avoidance less consistently? Comparing two diverse behavioral paradigms is difficult, since there are many parameters that differ. However, we are confident that this type of approach is necessary, and will be useful. We have developed another behavioral paradigm using conditioned place preference (E. Friedman, personal communication). In the place preference behavioral assay, the 807 transgene enhances memory formation consistently, reinforcing our conclusion that the $28 \mathrm{kDa}$ protein can have important effects on memory formation. We are currently trying to determine what behavioral factor(s) differ between courtship suppression and place preference (where we see consistent enhancement) and olfactory avoidance (where enhancement is less consistent). One possibility is that enhancement in flies specifically requires a "behavioral state" that is difficult to control experimentally, and which can be epistatic to the other parameters such as expression levels, activity windows, and the time-of-day of training. This behavioral state appears to be an "all-ornothing" group effect, with all of the flies in a given experiment affected similarly.

Recent work using acute interventions in mice and other systems has shown that increasing CREB activity increases the intrinsic excitability of neurons, while interfering with CREB activity has the opposite effect (Dong et al., 2006; Han et al., 2006; Han et al., 2007; Lopez de Armentia et al., 2007; Viosca et al., 2009; Wallace et al., 2009; Zhou et al., 2009; Cao et al., 2010; Liu et al., 2011; Suzuki et al., 2011). The CREB-dependent increase in excitability is correlated with memory enhancement, and vice versa. If dCREB2 enhances memory formation partially through affecting the excitability of relevant neurons, then the "excitable state" of those neurons at the time of training might determine whether additional dCREB2 protein has enhancing potential or not (Benito and Barco, 2010). Since excitability is saturable, there 
are two simple outcomes, depending upon the state of the neurons at the time of training. If neurons are more quiescent, dCREB2 induction can increase excitability, and enhancement will occur in response to training (relative to equally quiescent neurons that just receive training). However, if the neurons are already excitable at the time of training, then extra dCREB2 will not have any effect, since excitability is saturable. The pretraining handling and housing of flies differs between various behaviors, and is somewhat variable even with the same behavior. These parameters could affect the baseline excitability of the flies, and indirectly affect enhancement. Our behavioral data are consistent with this view, since enhancement usually becomes significant when the control fly population has lower memory scores, rather than the experimental population having higher memory scores. The effect of the time-of-day on enhancement (Fig. 6) also is consistent with this general hypothesis, since excitability is known to vary across the circadian cycle, at least for certain neurons (Cao and Nitabach, 2008; Ko et al., 2009). We are currently testing this possibility, and its relevance has important implications for the role that dCREB2 plays in memory formation in a non-transgenic fly.

\section{References}

Ahmed T, Frey JU (2005) Plasticity-specific phosphorylation of CaMKII, MAP-kinases and CREB during late-LTP in rat hippocampal slices in vitro. Neuropharmacology 49:477-492. CrossRef Medline

Alberini CM (2009) Transcription factors in long-term memory and synaptic plasticity. Physiol Rev 89:121-145. CrossRef Medline

Alzoubi KH, Alkadhi KA (2007) A critical role of CREB in the impairment of late-phase LTP by adult onset hypothyroidism. Exp Neurol 203:63-71. CrossRef Medline

Barco A, Alarcon JM, Kandel ER (2002) Expression of constitutively active CREB protein facilitates the late phase of long-term potentiation by enhancing synaptic capture. Cell 108:689-703. CrossRef Medline

Barco A, Patterson SL, Alarcon JM, Gromova P, Mata-Roig M, Morozov A, Kandel ER (2005) Gene expression profiling of facilitated L-LTP in VP16-CREB mice reveals that BDNF is critical for the maintenance of LTP and its synaptic capture. Neuron 48:123-137. CrossRef Medline

Bartsch D, Casadio A, Karl KA, Serodio P, Kandel ER (1998) CREB1 encodes a nuclear activator, a repressor, and a cytoplasmic modulator that form a regulatory unit critical for long-term facilitation. Cell 95:211-223. CrossRef Medline

Belvin MP, Zhou H, Yin JC (1999) The Drosophila dCREB2 gene affects the circadian clock. Neuron 22:777-787. CrossRef Medline

Benito E, Barco A (2010) CREB's control of intrinsic and synaptic plasticity: implications for CREB-dependent memory models. Trends Neurosci 33: 230-240. CrossRef Medline

Blendy JA, Kaestner KH, Schmid W, Gass P, Schutz G (1996) Targeting of the CREB gene leads to upregulation of a novel CREB mRNA isoform. EMBO J 15:1098-1106. Medline

Bozon B, Kelly A, Josselyn SA, Silva AJ, Davis S, Laroche S (2003) MAPK, CREB and zif268 are all required for the consolidation of recognition memory. Philos Trans R Soc Lond B Biol Sci 358:805-814. CrossRef Medline

Brightwell JJ, Smith CA, Countryman RA, Neve RL, Colombo PJ (2005) Hippocampal overexpression of mutant CREB blocks long-term, but not short-term memory for a socially transmitted food preference. Learn Mem 12:12-17. CrossRef Medline

Brightwell JJ, Smith CA, Neve RL, Colombo PJ (2007) Long-term memory for place learingin is facilitated by expression of cAMP responsive element-binding protein in the dorsal hippocampus. Learn Mem 14:195199. CrossRef Medline

Cao G, Nitabach MN (2008) Circadian control of membrane excitability in Drosophila melanogaster lateral ventral clock neurons. J Neurosci 28: 6493-6501. CrossRef Medline

Cao JL, Vialou VF, Lobo MK, Robison AJ, Neve RL, Cooper DC, Nestler EJ, Han MH (2010) Essential role of the cAMP-cAMP response-element binding protein pathway in opiate-induced homeostatic adaptations of locus coeruleus neurons. Proc Natl Acad Sci U S A 107:17011-17016. CrossRef Medline

Chaudhury D, Wang LM, Colwell CS (2005) Circadian regulation of hippocampal long-term potentiation. J Biol Rhythms 20:225-236. CrossRef Medline

Comerford KM, Leonard MO, Karhausen J, Carey R, Colgan SP, Taylor CT (2003) Small ubiquitin-related modifier-1 modification mediates resolution of CREB-dependent responses to hypoxia. Proc Natl Acad Sci U S A 100:986-991. CrossRef Medline

Dash PK, Hochner B, Kandel ER (1990) Injection of the cAMP-responsive element binding protein into the nucleus of Aplysia sensory neurons blocks long-term facilitation. Nature 345:718-721. CrossRef Medline

Davis GW, Schuster CM, Goodman CS (1996) Genetic dissection of structural and functional components of synaptic plasticity. III. CREB is necessary for presynaptic functional plasticity. Neuron 17:669-679. CrossRef Medline

Delmas V, Laoide BM, Masquilier D, de Groot RP, Foulkes NS, Sassone-Corsi P (1992) Alternative usage of initiation codons in mRNA encoding the cAMP-responsive-element modulator generates regulators with opposite functions. Proc Natl Acad Sci U S A 89:4226-4230. CrossRef Medline

Demczuk S, Harbers M, Vennström B (1993) Identification and analysis of all components of a gel retardation assay by combination with immunoblotting. Proc Natl Acad Sci U S A 90:2574-2578. CrossRef Medline

Dong Y, Green T, Saal D, Marie H, Neve R, Nestler EJ, Malenka RC (2006) CREB modulates excitability of nucleus accumbens neurons. Nat Neurosci 9:475-477. Medline

Eckel-Mahan KL, Phan T, Han S, Wang H, Chan GC, Scheiner ZS, Storm DR (2008) Circadian oscillation of hippocampal MAPK activity and cAMP: implications for memory persistence. Nat Neurosci 11:1074-1082. CrossRef Medline

Ejima A, Griffith LC (2011) Assay for courtship suppression in Drosophila. Cold Spring Harb Protoc 2011(2):pdb.prot5575. CrossRef Medline

Fernandez RI, Lyons LC, Levenson J, Khabour O, Eskin A (2003) Circadian modulation of long-term sensitization in Aplysia. Proc Natl Acad Sci U S A 100:14415-14420. CrossRef Medline

Gonzalez GA, Yamamoto KK, Fischer WH, Karr D, Menzel P, Biggs W 3rd, Vale WW, Montminy MR (1989) A cluster of phosphorylation sites on the cyclic AMP-regulated nuclear factor CREB predicted by its sequence. Nature 337:749-752. CrossRef Medline

Goren I, Tavor E, Goldblum A, Honigman A (2001) Two cysteine residues in the DNA-binding domain of CREB control binding to CRE and CREBmediated gene expression. J Mol Biol 313:695-709. CrossRef Medline

Guzowski JF, McGaugh JL (1997) Antisense oligodeoxynucleotidemediated disruption of hippocampal cAMP response element binding protein levels impairs consolidation of memory for water maze training. Proc Natl Acad Sci U S A 94:2693-2698. CrossRef Medline

Han JH, Kushner SA, Yiu AP, Cole CJ, Matynia A, Brown RA, Neve RL, Guzowski JF, Silva AJ, Josselyn SA (2007) Neuronal competition and selection during memory formation. Science 316:457-460. CrossRef Medline

Han JH, Yiu AP, Cole CJ, Hsiang HL, Neve RL, Josselyn SA (2008) Increasing CREB in the auditory thalamus enhances memory and generalization of auditory conditioned fear. Learn Mem 15:443-453. CrossRef Medline

Han MH, Bolaños CA, Green TA, Olson VG, Neve RL, Liu RJ, Aghajanian GK, Nestler EJ (2006) Role of cAMP response element-binding protein in the rat locus ceruleus: regulation of neuronal activity and opiate withdrawal behaviors. J Neurosci 26:4624-4629. CrossRef Medline

Hendricks JC, Williams JA, Panckeri K, Kirk D, Tello M, Yin JC, Sehgal A (2001) A non-circadian role for cAMP signaling and CREB activity in Drosophila rest homeostasis. Nat Neurosci 4:1108-1115. CrossRef Medline

Horiuchi J, Jiang W, Zhou H, Wu P, Yin JC (2004) Phosphorylation of conserved casein kinase sites regulates cAMP-response element-binding protein DNA binding in Drosophila. J Biol Chem 279:12117-12125. Medline

Hotte M, Thuault S, Dineley KT, Hemmings HC Jr, Nairn AC, Jay TM (2007) Phosphorylation of CREB and DARPP-32 during late LTP at hippocampal to prefrontal cortex synapses in vivo. Synapse 61:24-28. CrossRef Medline

Impey S, Smith DM, Obrietan K, Donahue R, Wade C, Storm DR (1998) Stimulation of cAMP response element (CRE)-mediated transcription during contextual learning. Nat Neurosci 1:595-601. CrossRef Medline 
Izquierdo LA, Barros DM, Vianna MR, Coitinho A, deDavid e Silva T, Choi H, Moletta B, Medina JH, Izquierdo I (2002) Molecular pharmacological dissection of short- and long-term memory. Cell Mol Neurobiol 22: 269-287. CrossRef Medline

Jasnow AM, Shi C, Israel JE, Davis M, Huhman KL (2005) Memory of social defeat is facilitated by cAMP-response element-binding protein overexpression in the amygdala. Behav Neurosci 119:1125-1130. CrossRef Medline

Josselyn SA, Nguyen PV (2005) CREB, synapses and memory disorders: past progress and future challenges. Curr Drug Targets CNS Neurol Disord 4:481-497. CrossRef Medline

Josselyn SA, Shi C, Carlezon WA Jr, Neve RL, Nestler EJ, Davis M (2001) Long-term memory is facilitated by cAMP response element-binding protein overexpression in the amygdala. J Neurosci 21:2404-2412. Medline

Josselyn SA, Kida S, Silva AJ (2004) Inducible repression of CREB function disrupts amygdala-dependent memory. Neurobiol Learn Mem 82:159163. CrossRef Medline

Kida S, Josselyn SA, Peña de Ortiz S, Kogan JH, Chevere I, Masushige S, Silva AJ (2002) CREB required for the stability of new and reactivated fear memories. Nat Neurosci 5:348-355. CrossRef Medline

Ko GY, Shi L, Ko ML (2009) Circadian regulation of ion channels and their functions. J Neurochem 110:1150-1169. CrossRef Medline

Lamarre-Vincent N, Hsieh-Wilson LC (2003) Dynamic glycosylation of the transcription factor CREB: a potential role in gene regulation. J Am Chem Soc 125:6612-6613. CrossRef Medline

Lamprecht R, Hazvi S, Dudai Y (1997) cAMP response element-binding protein in the amygdala is required for long- but not short-term conditioned taste aversion memory. J Neurosci 17:8443-8450. Medline

Leutgeb JK, Frey JU, Behnisch T (2005) Single cell analysis of activitydependent cyclic AMP-responsive element-binding protein phosphorylation during long-lasting long-term potentiation in area CA1 of mature rat hippocampal-organotypic cultures. Neuroscience 131:601-610. CrossRef Medline

Liu RY, Cleary LJ, Byrne JH (2011) The requirement for enhanced CREB1 expression in consolidation of long-term synaptic facilitation and longterm excitability in sensory neurons of Aplysia. J Neurosci 31:6871-6879. CrossRef Medline

Lonze BE, Ginty DD (2002) Function and regulation of CREB family transcription factors in the nervous system. Neuron 35:605-623. CrossRef Medline

Lopez de Armentia M, Jancic D, Olivares R, Alarcon JM, Kandel ER, Barco A (2007) cAMP response element-binding protein-mediated gene expression increases the intrinsic excitability of CA1 pyramidal neurons. J Neurosci 27:13909-13918. CrossRef Medline

Lyons LC, Rawashdeh O, Katzoff A, Susswein AJ, Eskin A (2005) Circadian modulation of complex learning in diurnal and nocturnal Aplysia. Proc Natl Acad Sci U S A 102:12589-12594. CrossRef Medline

Lyons LC, Collado MS, Khabour O, Green CL, Eskin A (2006) The circadian clock modulates core steps in long-term memory formation in Aplysia. J Neurosci 26:8662-8671. CrossRef Medline

Miyamoto E (2006) Molecular mechanism of neuronal plasticity: induction and maintenance of long-term potentiation in the hippocampus. J Pharmacol Sci 100:433-442. CrossRef Medline

Mouravlev A, Dunning J, Young D, During MJ (2006) Somatic gene transfer of cAMP response element-binding protein attenuates memory impairment in aging rats. Proc Natl Acad Sci U S A 103:4705-4710. CrossRef Medline

Perazzona B, Isabel G, Preat T, Davis RL (2004) The role of cAMP response element-binding protein in Drosophila long-term memory J Neurosci 24:8823-8828. CrossRef

Philips GT, Tzvetkova EI, Carew TJ (2007) Transient mitogen-activated protein kinase activation is confined to a narrow temporal window required for the induction of two-trial long-term memory in Aplysia. J Neurosci 27:13701-13705. CrossRef Medline

Riccio A, Alvania RS, Lonze BE, Ramanan N, Kim T, Huang Y, Dawson TM, Snyder SH, Ginty DD (2006) A nitric oxide signaling pathway controls CREB-mediated gene expression in neurons. Mol Cell 21:283-294. CrossRef Medline

Ruby NF, Hwang CE, Wessells C, Fernandez F, Zhang P, Sapolsky R, Heller
HC (2008) Hippocampal-dependent learning requires a functional circadian system. Proc Natl Acad Sci U S A 105:15593-15598. CrossRef Medline

Sakai T, Tamura T, Kitamoto T, Kidokoro Y (2004) A clock gene, period, plays a key role in long-term memory formation in Drosophila. Proc Natl Acad Sci U S A 101:16058-16063. CrossRef Medline

Schulz S, Siemer H, Krug M, Höllt V (1999) Direct evidence for biphasic cAMP responsive element-binding protein phosphorylation during longterm potentiation in the rat dentate gyrus in vivo. J Neurosci 19:56835692. Medline

Shaywitz AJ, Greenberg ME (1999) CREB: a stimulus-induced transcription factor activated by a diverse array of extracellular signals. Annu Rev Biochem 68:821-861. CrossRef Medline

Siegel RW, Hall JC (1979) Conditioned responses in courship behavior of normal and mutant Drosophila. Proc Natl Acad Sci U S A 76:3430-3434. Medline

Suzuki A, Fukushima H, Mukawa T, Toyoda H, Wu LJ, Zhao MG, Xu H, Shang Y, Endoh K, Iwamoto T, Mamiya N, Okano E, Hasegawa S, Mercaldo V, Zhang Y, Maeda R, Ohta M, Josselyn SA, Zhuo M, Kida S (2011) Upregulation of CREB-mediated transcription enhances both short- and long-term memory. J Neurosci 31:8786-8802. CrossRef Medline

Tao X, Finkbeiner S, Arnold DB, Shaywitz AJ, Greenberg ME (1998) $\mathrm{Ca}^{2+}$ influx regulates BDNF transcription by a CREB family transcription factor-dependent mechanism. Neuron 20:709-726. CrossRef Medline

Tully T, Quinn WG (1985) Classical conditioning and retention in normal and mutant Drosophila melanogaster. J Comp Physiol A 157:263-277. CrossRef Medline

Tully T, Preat T, Boynton SC, Del Vecchio M (1994) Genetic dissection of consolidated memory in Drosophila. Cell 79:35-47. CrossRef Medline

Viosca J, Lopez de Armentia M, Jancic D, Barco A (2009) Enhanced CREBdependent gene expression increases the excitability of neurons in the basal amygdala and primes the consolidation of contextual and cued fear memory. Learn Mem 16:193-197. Medline

Wagatsuma A, Azami S, Sakura M, Hatakeyama D, Aonuma H, Ito E (2006) De Novo synthesis of CREB in a presynaptic neuron is required for synaptic enhancement involved in memory consolidation. J Neurosci Res 84:954-960. CrossRef Medline

Wallace DL, Han MH, Graham DL, Green TA, Vialou V, Iñiguez SD, Cao JL, Kirk A, Chakravarty S, Kumar A, Krishnan V, Neve RL, Cooper DC, Bolaños CA, Barrot M, McClung CA, Nestler EJ (2009) CREB regulation of nucleus accumbens excitability mediates social isolation-induced behavioral deficits. Nat Neurosci 12:200-209. CrossRef Medline

Warburton EC, Glover CP, Massey PV, Wan H, Johnson B, Bienemann A, Deuschle U, Kew JN, Aggleton JP, Bashir ZI, Uney J, Brown MW (2005) cAMP responsive element-binding protein phosphorylation is necessary for perirhinal long-term potentiation and recognition memory. J Neurosci 25:6296-6303. CrossRef Medline

Yin JC, Tully T (1996) CREB and the formation of long-term memory. Curr Opin Neurobiol 6:264-268. CrossRef Medline

Yin JC, Wallach JS, Del Vecchio M, Wilder EL, Zhou H, Quinn WG, Tully T (1994) Induction of a dominant negative CREB transgene specifically blocks long-term memory in Drosophila. Cell 79:49-58. CrossRef Medline

Yin JC, Del Vecchio M, Zhou H, Tully T (1995a) CREB as a memory modulator: induced expression of a dCREB2 activator isoform enhances longterm memory in Drosophila. Cell 81:107-115. CrossRef Medline

Yin JC, Wallach JS, Wilder EL, Klingensmith J, Dang D, Perrimon N, Zhou H, Tully T, Quinn WG (1995b) A Drosophila CREB/CREM homolog encodes multiple isoforms, including a cyclic AMP-dependent protein kinase-responsive transcriptional activator and antagonist. Mol Cell Biol 15:5123-5130. Medline

Zhang JJ, Okutani F, Inoue S, Kaba H (2003) Activation of the cyclic AMP response element-binding protein signaling pathway in the olfactory bulb is required for the acquisition of olfactory aversive learning in young rats. Neuroscience 117:707-713. CrossRef Medline

Zhou Y, Won J, Karlsson MG, Zhou M, Rogerson T, Balaji J, Neve R, Poirazi P, Silva AJ (2009) CREB regulates excitability and the allocation of memory to subsets of neurons in the amygdala. Nat Neurosci 12:1438 1443. CrossRef Medline 